\title{
The Productivity and Quality of Work Life in Emergency Nurses
}

\author{
Mojtaba Karimi ${ }^{1}$, Parisa Bozorgzad ${ }^{2}$, Tahereh Najafi Ghezeljeh ${ }^{3}$, Hamid Haghani ${ }^{4}$, \\ Bahareh Fallah ${ }^{5}$
}

\begin{abstract}
Background \& Aims: The emergency department is the heart of the hospital and the entry point for patients to receive health services and emergency nurses are one of the largest working groups in the hospital and the most influential force in determining the quality of services provided. The main mission of this department is to save the lives of patients. Therefore, emergency department nurses have big responsibility and it is necessary to have the necessary professional motivation and commitment along with sufficient knowledge and skills. In recent years, there has been a lot of focus on factors that can guarantee or impair the quality of emergency services, and all hospitals have tried to make the most of available resources to strengthen the factors with a positive impact on service quality. Productivity is a comprehensive concept that is closely related to effectiveness and efficiency. Several factors are involved in the organization productivity and the most important ones are human factors. On the other hand, a healthy and balanced work environment plays an important role in minimizing burnout and job stress and, consequently, improving the quality of services and productivity. Due to its importance, Human force productivity is considered as one of the indices of success or failure in any organization and its evaluation is one of the priorities of organization development. Therefore, one of the major challenges of health care systems is to provide quality services with a focus on increasing the quality of life of health care workers and increasing productivity. Therefore, information about the productivity and quality of work life of staff can be a basis for taking appropriate measures and preparing the ground for achieving the desired conditions. This study aimed to determine the productivity and quality of work life of emergency department nurses.

Materials \& Methods: This descriptive cross-sectional study was conducted on 189 nurses working in the emergency department of educational and medical centers affiliated to Shahid Sadoughi University of Medical Sciences during September-November 2016. The nurses were selected through stratified allocation method. Data were collected using a demographic questionnaire, nurses' productivity questionnaire (Dehghan Naieri et al., 2013) and quality of work life questionnaire (Brooks \& Anderson, 2005). ANOVA and t-test were used to analyze the data in SPSS version 16.

Results: The mean productivity of nurses working in the emergency department was $92.55 \pm 11.68$. The average score of total quality of work life was $143.67 \pm 26.98$. The quality of work life had the highest average score in the dimension of work (3.58) and the lowest average score in the personal life dimension (3.04). The results showed no statistically significant relationship between any of the demographic characteristics and nurses' work productivity. Among the studied job characteristics, there was a statistically significant relationship between simultaneous employment and the productivity of emergency nurses

\footnotetext{
1. Master of Emergency Nursingof Emergency Nursing, School of Nursing and Midwifery, Iran University of Medical Sciences, Tehran, Iran

2. Department of Critical Care Nursing, School of Nursing and Midwifery, Iran University of Medical Sciences, Tehran, Iran (Corresponding author) Tel:09121869462 Email: bozorgzad.P@iums.ac.ir

3. Department of Critical Care Nursing, Nursing Care Research Center (NCRC), School Nursing and Midwifery, Iran University of Medical Sciences, Tehran, Iran

4. Department of Biostatistics, School of Health, Iran University of Medical Sciences, Tehran, Iran

5. Nursing Faculty Member, Trauma Research Center, School of Nursing and Midwifery, Shahid Sadoughi University of Medical Sciences, Yazd, Iran
} 
$(\mathrm{P}<0.05)$. There was also a statistically significant relationship between nurses' quality of work life with marital status $(\mathrm{P}<0.01)$ and education $(\mathrm{P}<0.05)$. Working overtime $(\mathrm{P}<0.05)$ and choice of working hours $(\mathrm{P}<0.01)$ had a statistically significant relationship with the quality of work life of emergency nurses.

Conclusion: The findings of the present study showed that productivity and quality of work life in emergency nurses were at a moderate and relatively desirable level, respectively. This finding can help nursing planners to increase the productivity of nurses by investigating the causes of this problem and reducing it. For example, financial need in many cases leads the people to work in several environments, and planning to solve financial problems can reduce simultaneous employment and thus increase productivity. In particular, emergency nurses are responsible for vital activities, and sometimes the first error costs the patient's life. It was also found that mere academic promotion based on a degree could not be a reason to improve the quality of work life. Awareness of nurses about these findings can improve these variables and increase their satisfaction and organizational productivity. Therefore, there is still a long way towards achieving the desired productivity and quality of life and require planning. Therefore, it is necessary to make comprehensive plans to improve the productivity and quality of work life of nurses. This planning can be done at the macro level by senior managers of the health system and at the micro level by the management of the hospital complex. It should be noted that due to the importance of the issue and the role of productivity and quality of work life in providing health care services and the emergency department which plays a vital role in hospitals, it is recommended that studies be conducted on larger sample size and more diverse research community. Also, the factors affecting the quality of life of single nurses and the reason for the decrease in their average quality of work life, and factors related to the decrease in productivity of nurses with a master's degree compared to nurses with a bachelor's degree should be examined in future research.

\section{Keywords: Productivity, Quality of Work Life, Emergency Nurses}

\section{Conflict of Interest: No}

How to Cite: Karimi M, Bozorgzad P, Najafi Ghezeljeh T, Haghani H, Fallah B. The Productivity and Quality of Work Life in Emergency Nurses. Iran Journal of Nursing. 2021; 34(130):73-90.

Received: 16 March 2021

Accepted: 19 Jun 2021 


\title{
بهرهورى و كيفيت زندگى كارى برستاران اورزانس
}

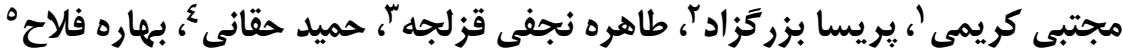

\section{جكيده}

زمينه و هدف: يرستاران اورزانس يكى از بزرگترين گروههاى كارى در بيمارستان و تأثيركذارترين نيروها در تعيين كيفيت خدمات ارائه شده

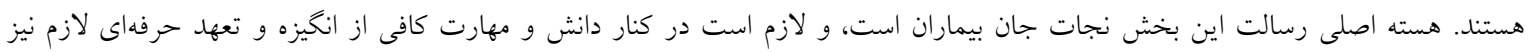

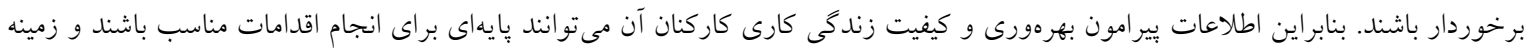

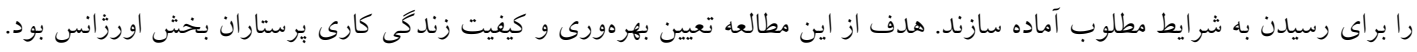

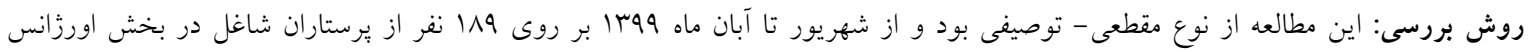

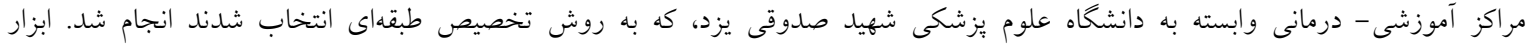

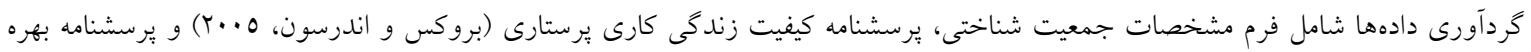

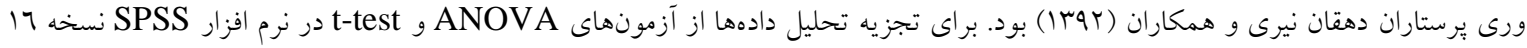

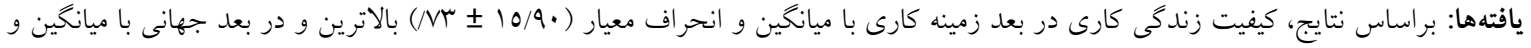

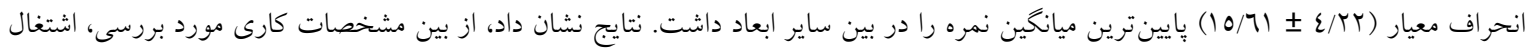

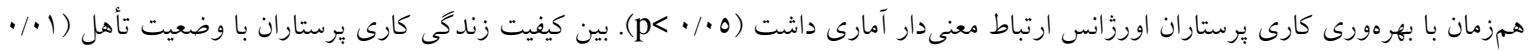

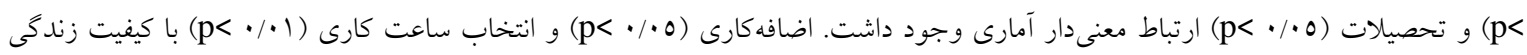

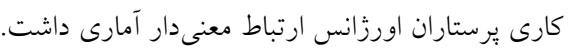
نتيجه گيرى كلى: با توجه به يافتها، ميانگين بهرهورى و كيفيت زندگى كارى در برستاران بخش اورزانس به ترتيب در سطح متوسط و نسبتا"

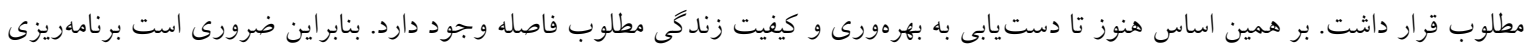

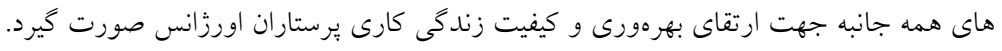

كليد وازهها: بهرهورى، كيفيت زندگى كارى، برستار اورزانس.

تعارض منافع: وجود ندارد.

تاريخ دريافت: 99/1

تاريخ بذيرش:

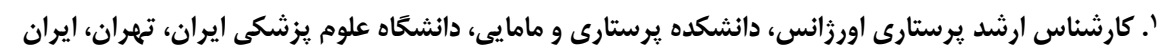

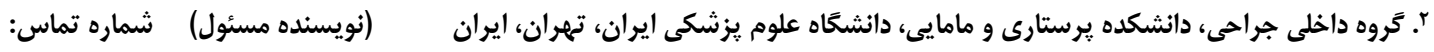

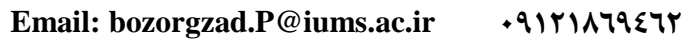

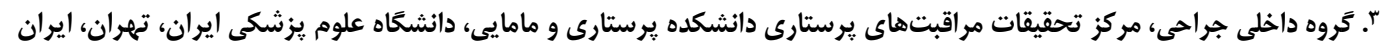

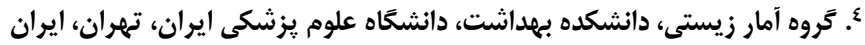

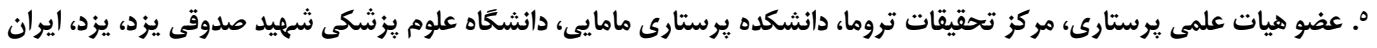



هميشه با فشار در ساختار سازمانى و حتى خارج از آن

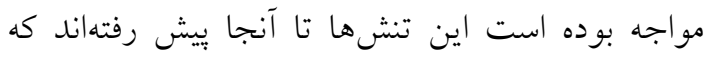

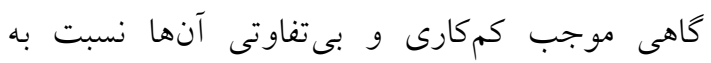

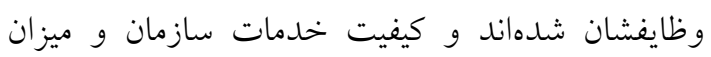
بهرهورى را تحت تأثير قرار دادهاند (·). برستاران نه تنها در خط مقدم مراقبتهاى سلامتى هستند، بلكه در خط مقدم اصلاح اين مراقبتها نيز قرار دارند و در بيشتر موارد ايجاد تغييرات، از برستاران آغاز مىشود. در ايالات متحده، تقريباً در تمام ايدههايى درئي كه براى اصلاح مراقبتهاى سلامتى مطرح شده است (از كاهش هزينههاى درمانى كرفته تا بهبود ايمنى بيمار تا حركت مراقبت در جامعه) يُرستاران نقش محورى

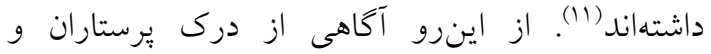

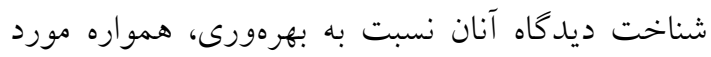

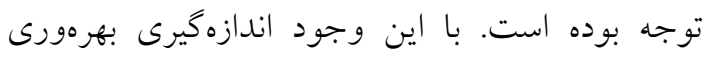

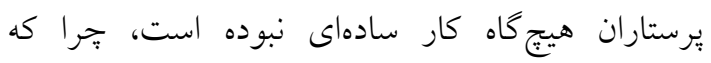
برخلاف يك خط توليد صنعتى، نتيجه كار الزاماً قابل

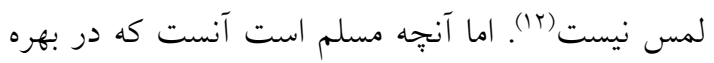

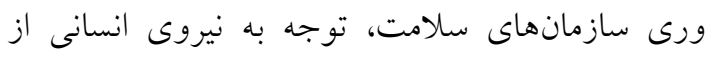

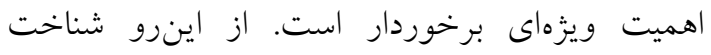

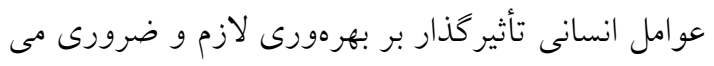
نمايد. دهقان نيرى و همكاران معتقدند، افزايش بهره ورى يرستاران در سيستمهاى سلامت وابسته به ومانه اقداماتى است كه براى حفظ جسم و روان بران برستاران شاغل در آن سيستمها انجام مى گيرد، و در اين ميان

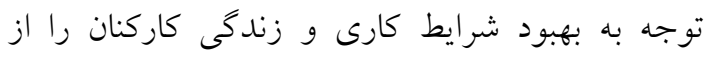

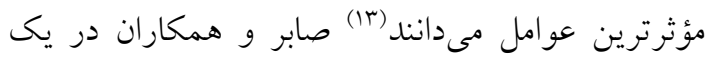
مطالعه مقطعى در يكى از مراكز درمانى كرمان نشان دادند كيفيت زندگى كارى و بهرهورى با يكديكر در ارتباط بوده و ارتقاء كيفيت زندكى كارى موجب

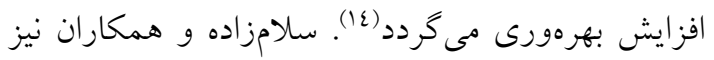
در مطالعهاى مشابه در بزرگترين مركز درمانى شهر يزد، نتايج يكسان بهدست آوردند (10). محيط كارى سالم و متوازن نقش به سزايى در به حداقل بهد رساندن

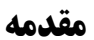

بخش اورزانس به عنوان قلب بيمارستان و نقطه ورود

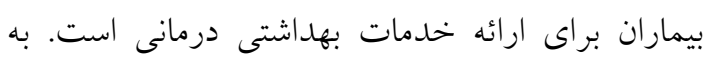
طورى كه VA درصد مراجعين به بيمارستانها را بيماران بخش اورزانس تشكيل مى دهد (1). و يرستاران اورزانس بهانس

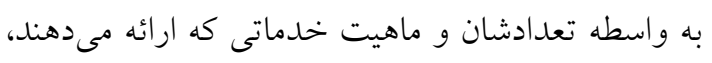
تأثير خذارترين نيروها در تعيين كيفيت خدمات نهات ارائه

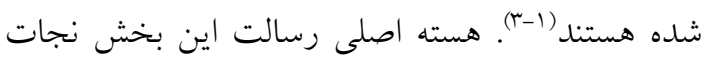
جان بيماران است، از اينرو افرادى كه در جنين مداخلاتى شركت دارند مسئوليت سنخينى برعهده دارند و لازم است در كنار دانش و مهارت كافى از انخيزه و

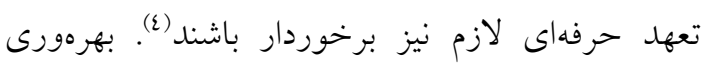

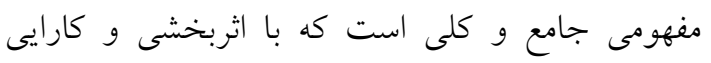

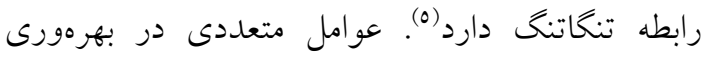
سازمان نقش دارند، كه از جمله مهمترين آنها مى توان

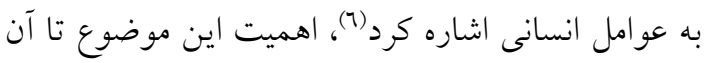

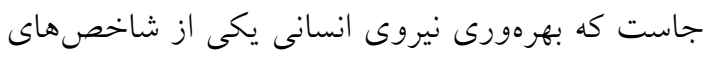

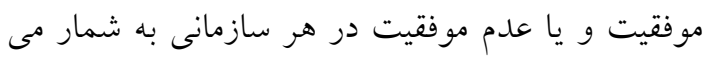

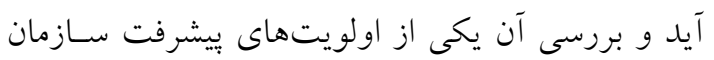

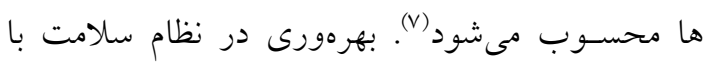

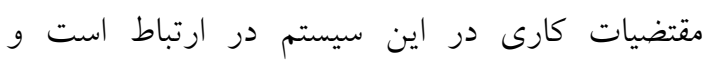

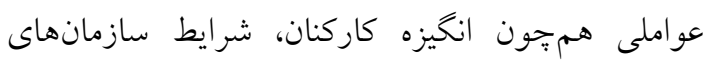

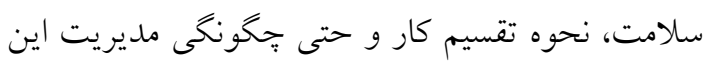

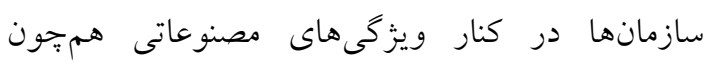

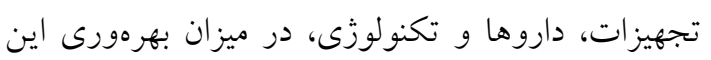

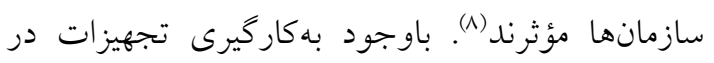

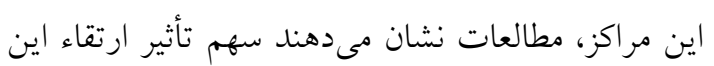
تجهيزات با تاثير نيروى انسانى اين سازمانها، بر بهره

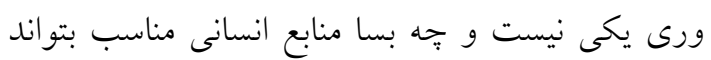

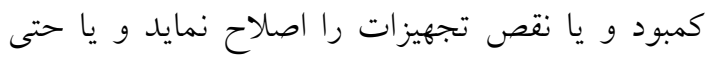

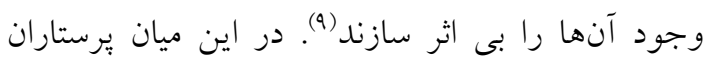

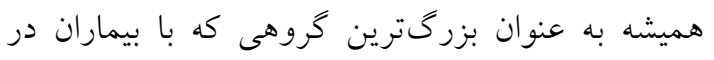

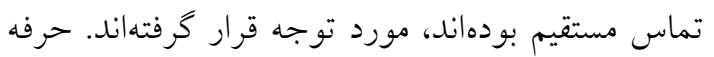
ى يرستارى به عنوان يكى از يرتنشترين مشاغل مرده 
شخصى را نيز تحت تأثير قرار دهد (19). بهعلاوه كيفيت

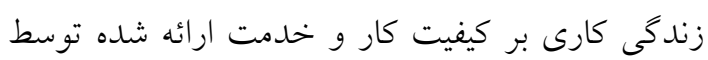

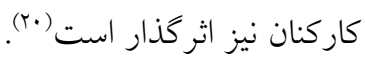
نتيجه تحقيقات اوليه Hathorn نشان داد بهبود روابط نيط كارى و ايجاد فرصت براى كاركنان به منظور دليذير

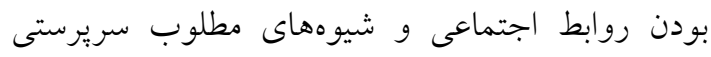

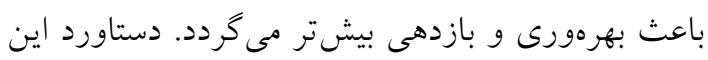

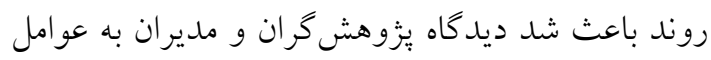

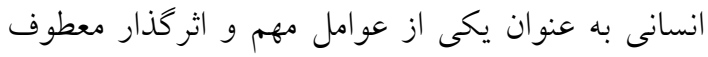

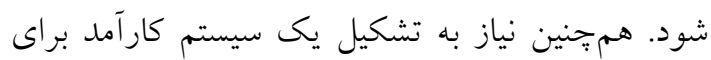

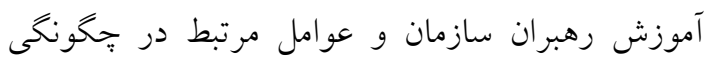

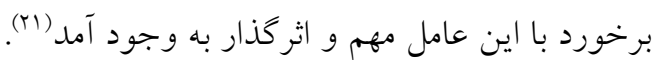
كيفيت زندكى كارى مطلوب، رضايت كاركنان را ران افزايش مىدهل، يادگيرى آنها را در محيط تقويت مىكند و به آنها در امر مديريت يارى مىدهد. فقدان رضايت از كيفيت زندكى كارى مشكلى است كه تقريباً به همه كاركنان بدون توجه به مقام و جايڤاه آنها

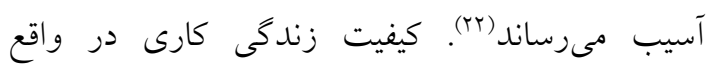
ديدكاه نوينى به رضايت شغلى است كه تلاش مى كند

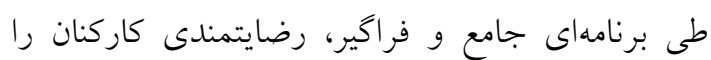

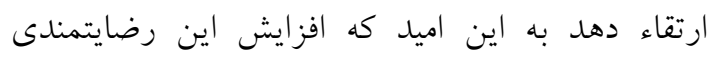

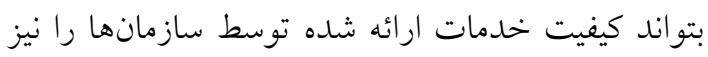
ارتقاء بخشد و موقعيت آنها را در دنياى رقابتى امروز مستحكم كند (Tr). سازمانها و مراكز بهداشتى نيز از اين امر مستثنى نيستند. سازمانهاى بهداشتى درمانى نقش حياتى در حفظ و نخهدارى سلامت عموم مردم دارند و بهعنوان يكى از مهمترين و بنيادىترين سازمانها و ادارت در حفظ سلامت جامعه به شمار مىرود(ع). در اين ميان، توجه به كيفيت زندگى كارى كاركنان بخش سلامت، به

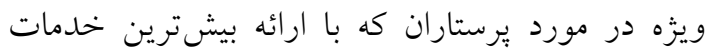
مستقيم به بيماران سهم عمدهاى در نمايان ساختن كيفيت خدمات سازمان دارند، حائز اهميت است (ro).
فرسودگى و استرس شغلى و به تبع آن ارتقاء كيفيت ارائه خدمات و ارتقاء بهرهورى دارد (17).

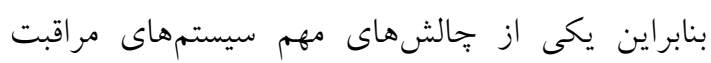

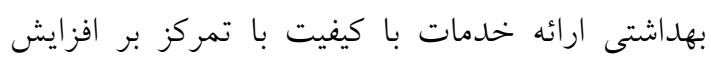

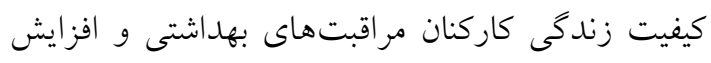
بهرهورى است. بهرهورى و كيفيت زندكى كارى با مشاركت يرستاران براى دستيابى به سطوح بالاتر ارائه خدمات ارتباط داشته اما مسئله مهم اين است كه شرايط

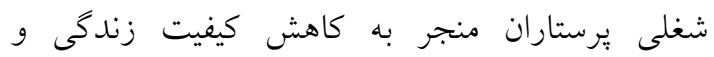

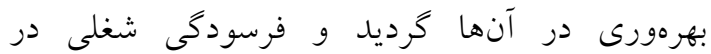
يرستاران مورد بررسى •^ درصد گزارش شد كه فرسودىى نيز خود بر كيفيت زندگى كارى و بهرهورى بردي

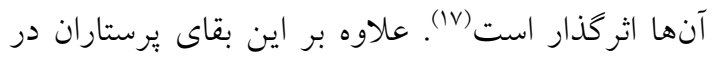

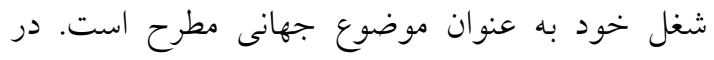

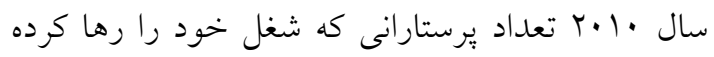

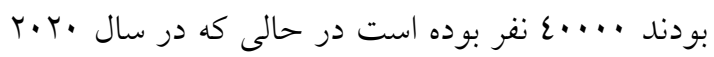

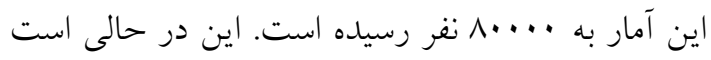

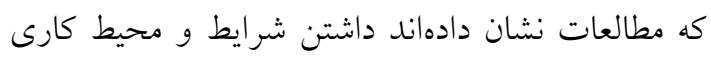
مناسب و كيفيت زندگى كارى در يرستاران بهرهورى را داده

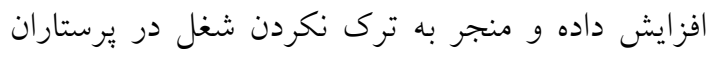

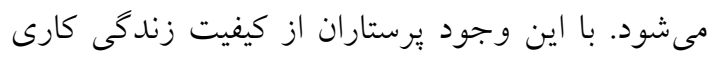

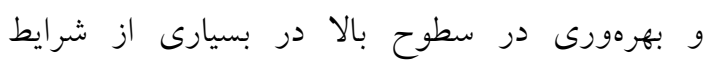
برخوردار نيستند و با ميانكين فاصله زيادى دارند.

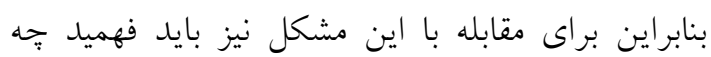
عواملى در محيط كار بر كيفيت زندكى كارى برى آنها

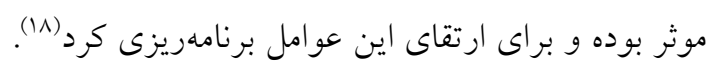
كيفيت زندكى كارى (Quality of Work Life)

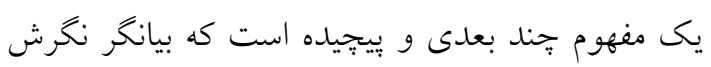

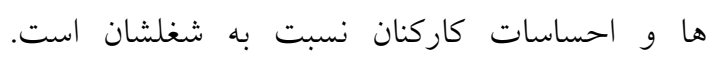
طرفداران نظريه كيفيت زندكى كارى در جستجوى نظام هاى جديدى براى كمك به كاركنان هستند تا بتواندا بين زندكى كارى و شخصى خود تعادل برقرار كنند،

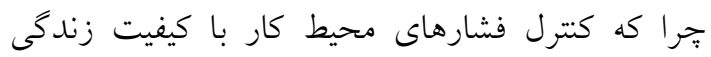
كارى مرتبط است كه خود مىتواند كيفيت زندكى 
توانند منعكس كننده شرايط كارى ايشان باشند، بررسى

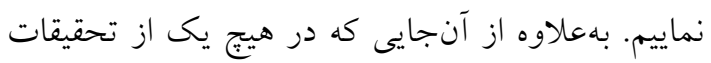
موجود يرستاران بخش اورزانس به صورت متمركز

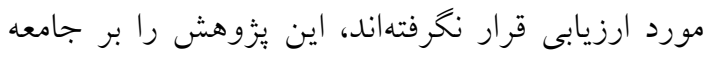
يرستاران شاغل در بخشهاى اورزانس بيمارستانها

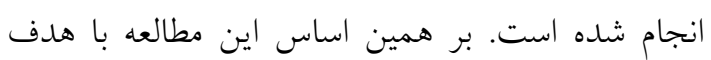

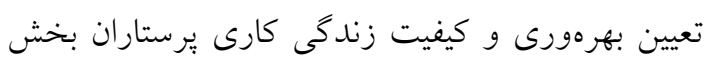

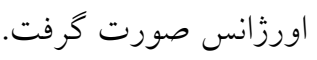

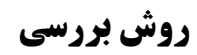

اين يُزوهش، بهصورت مقطعى، از نوع توصيفى بود كه

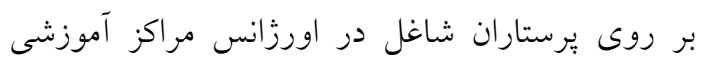

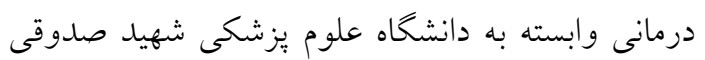

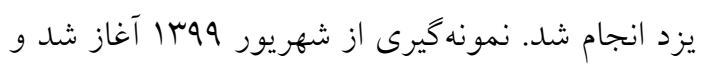

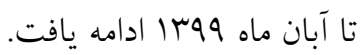
معيارهاى ورود به مطالعه دارا بودن مدرى تحصيلى بادي كارشناسى و بالاتر و داشتن حداقل شش ماه سابقه كار

$$
\text { در اورزانس بود. }
$$

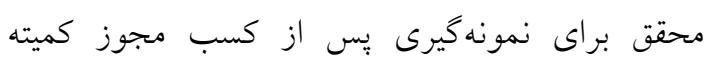
اخلاق (كد اخلاق اخذ معرفى نامه از دانشگاه علوم يزشكى ايران و و

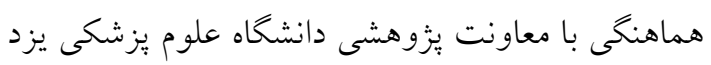

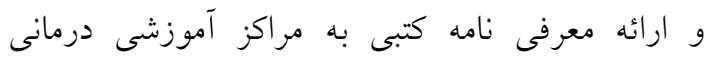

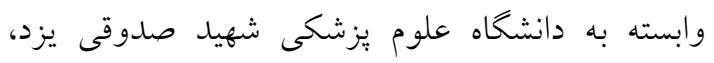

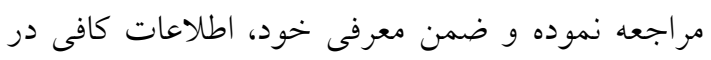
مورد اهداف يزّوهش و نحوه انجام كار را در اختيار يرستاران داوطلب يزوهش قرار داد و با كسب رضايت

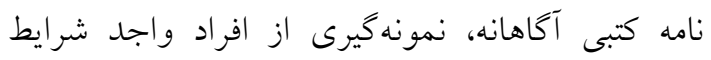
انجام شد. براى تعيين حجم نمونه در سطح اطمينان 90

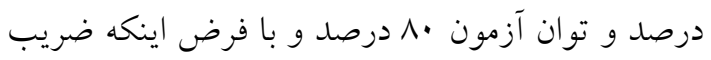

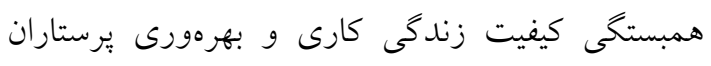

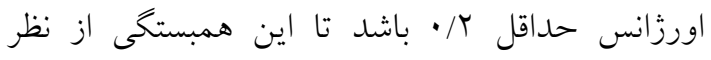

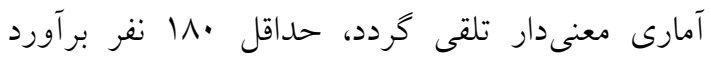

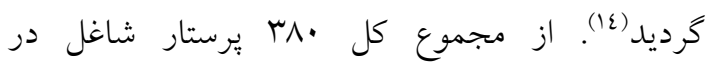

كيفيت زندگى كارى يرستارى اولين بار توسط Sطtridge و Callahan كيفيت زندكى كارى :برستاران وقتى ارتقاء مى يابد كه

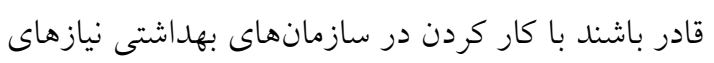

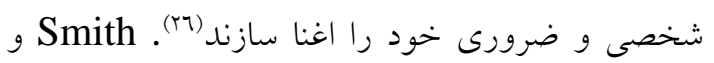
Hood كيفيت زندگى كارى مناسب نه تنها نيازهاى بايه كه نياز

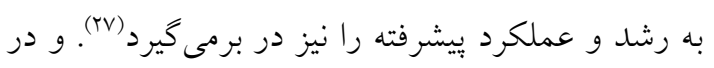

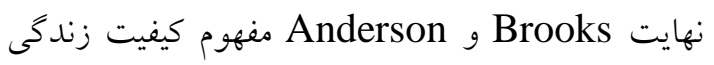

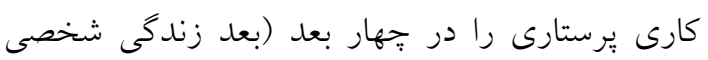
Work life/home life dimension جهارجوب كارى work design dimension زمينه كارى Work contex dimension و بعد بعدي

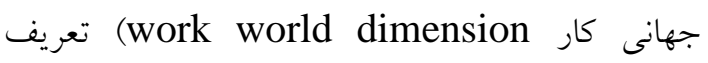
كردند (^^). بر همين اساس دانش حاصل از سنجش اين

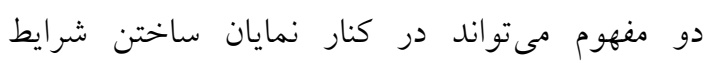
موجود، متضمن بيشنهاداتى براى رسيدن به شرايط

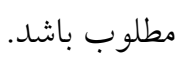

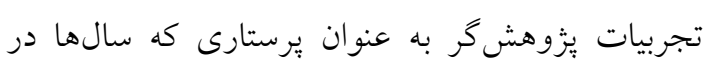
بخش اورزانس كار كرده است نشان مىدهد كه كاركنان

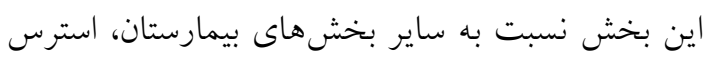

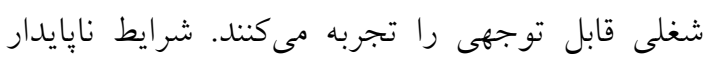

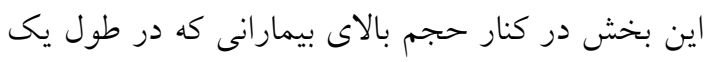

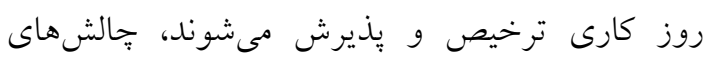

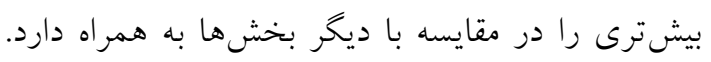
بهلعلاوه اين بخش به عنوان قلب مراكز درمانى و اولين

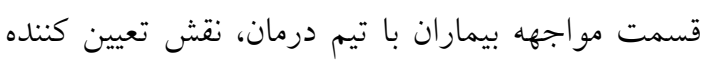

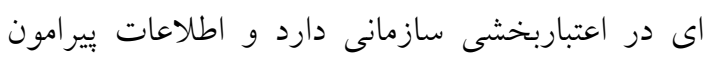
بهرهورى و كيفيت زندگى كارى كاركنان آن مىتوانند

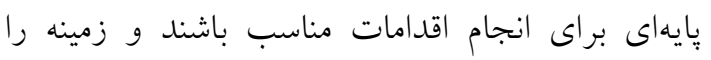
براى رسيدن به شرايط مطلوب آماده سازند.

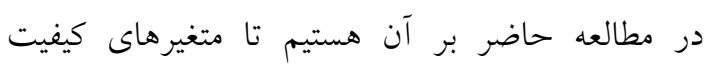
زندىى كارى و بهرهورى را با ابزارهايى كه بهطور

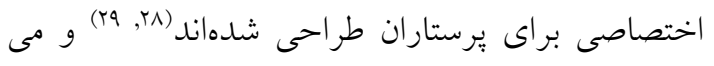


يزشكى كرمان قرار كرفت و ييشنهادات اصلاحى در

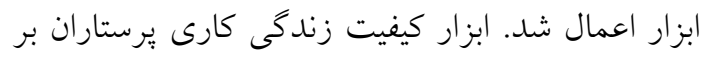

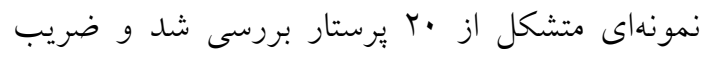

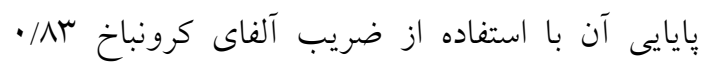

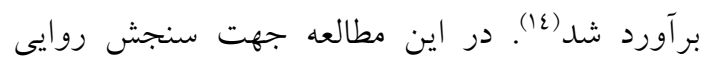

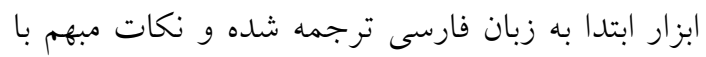
نظر تيم تحقيق تصحيح شد. سبس در اختيار داوران

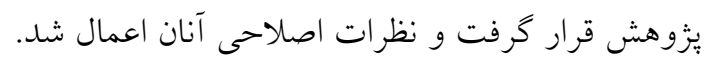
جهت بررسى ڤِيايیى، يرسشنامه در اختيار 10 نفر از يرستاران (كه جزء نمونهاى تحقيق نيستند) قرار كرفته و وايايیى درونى ابزار از طريق سنجش ضريب آلفا

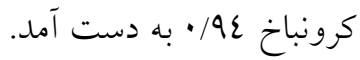

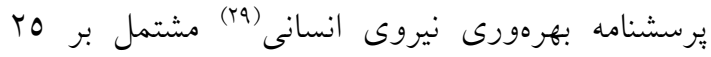
كويه كه ميزان بهرمورى برستاران را در طيف ليكرت

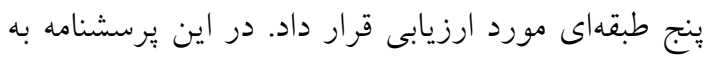

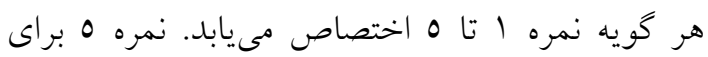

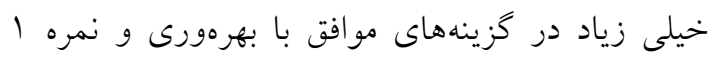

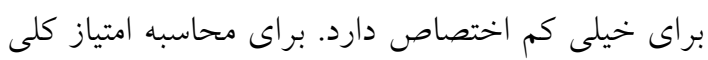

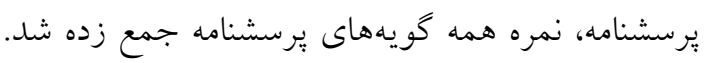

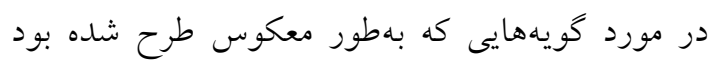

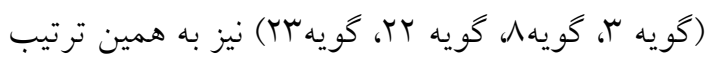
عمل شد. بدين ترتيب نمره TO براى كمترين بهرهورى

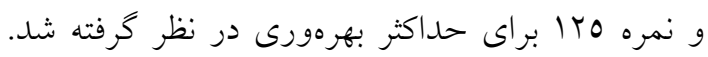
يرسشنامه بهرهورى يرستارى توسط دهقان نيرى و

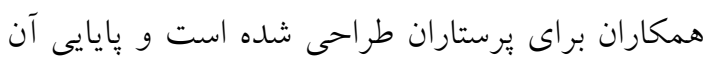

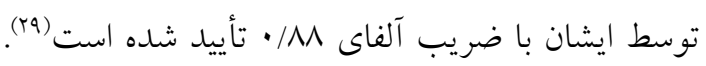
اين يرسشنامه در مطالعات متعدد مورد استفاده قرار

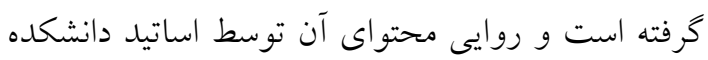

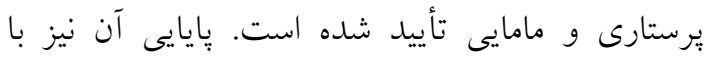

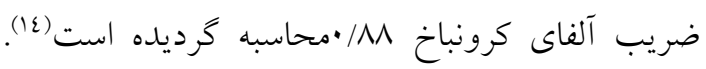
جهت بررسى پيايايى، يرسشنامه در اختيار 10 نفر از

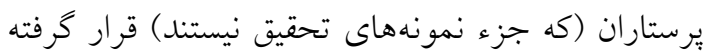

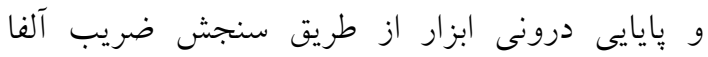

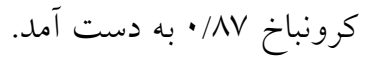

اورزانس بيمارستانها مبتنى بر معيارهاى ورود • •1 نفر از آنها به روش تخصيص طبقهاى، طى مدت سه ماه بهاه

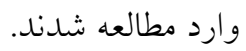
ابزار كردآورى اطلاعات شامل فرم مشخصات جمعيت ندان

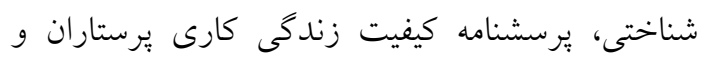
يرسشنامه بهرهورى يرستاران بود. فرم مشخصات جمعيت شناختى در اين يزوهش شامل سن، جنسيت،

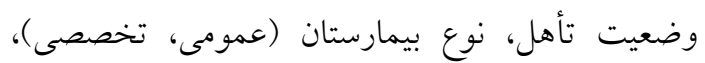

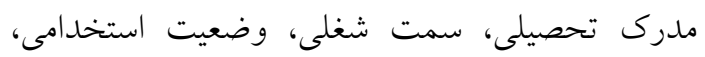

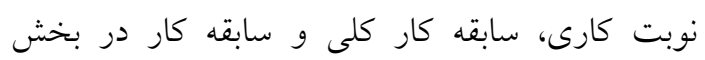
اورزانس بود. يرسشنامه كيفيت زندكى كارى يرستارى بروكس و اندرسون (Anderson \& Brooks)، شامل جهار بعد كيفيت زندكى كارى و داراى بـ سؤال با مقياس اندازهكيرى در طيف ليكرت ه طبقهاى است. بعد زندگى شخصى با V سؤال (سؤالات V-1)،

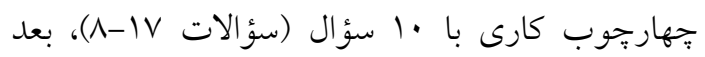

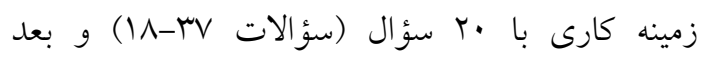

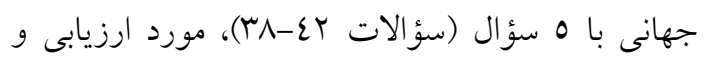

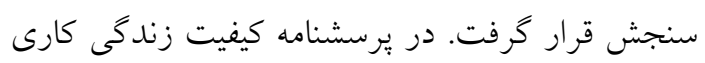

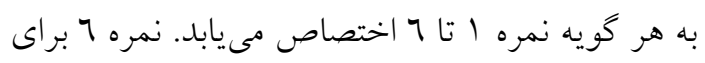

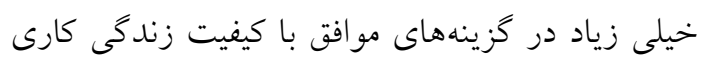

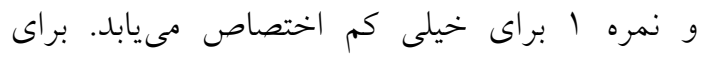

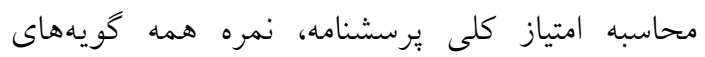

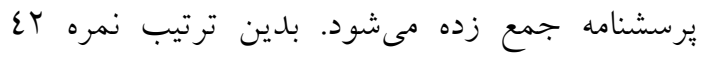

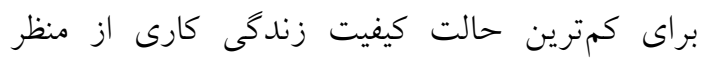
مشاركت كننده در يُزوهش و نمره ror حداكثر امتياز

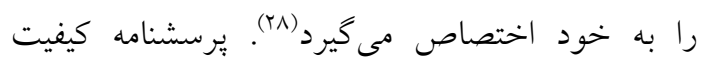
زندگى كارى يرستارى توسط بروكس (Brooks)

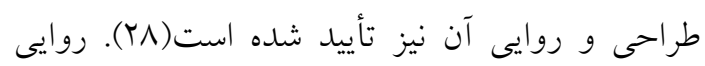
نسخه فارسى يرسشنامه كيفيت زندكى كارى يرستارى نيز توسط صابر و همكاران (Yrooks) سنجيده شده است. به اين منظور پِ از ترجمه توسط

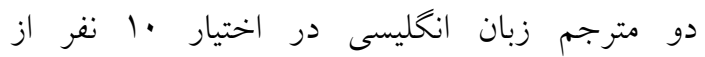
متخصصان و اساتيد داخل و خارج از دانشكاه علوم 
بر اساس جدول شماره ا، بيش از نيمى از يرستاران شركت كننده (r//.

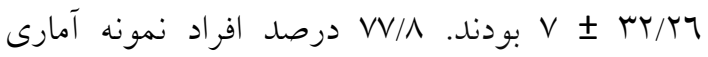
متأهل و سطح تحصيلات بيشتر افراد ( (T0\%)

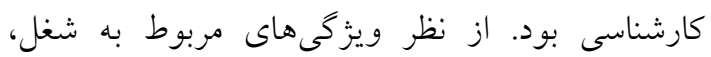

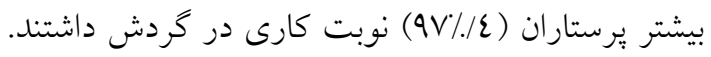
بيشتر يرستاران (N////N) دريافت كننده اضافه كارى و از نظر وضعيت انتخاب ساعت كارى بيشتر برستاران (07\%/0) در وضعيت اجبارى بودند. MN/2 درصد يرستاران فقط به عنوان يرستار بخش اورزانس مشغول و 11/7 درصد نيز همزمان در جاى ديكر مشغول به كار بودند. ميانخين و انحر اف معيار سابقه كارى برستاران در

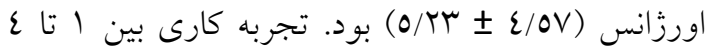
سال در اورزانس نيز با ON/T درصد از بيشترين فراوانى برخوردار بود (جدول شماره ().
در اين مطالعه تجزيه و تحليل دادهها با استفاده از نرم افزار SPSS نسخه 17 صورت كرفت. ابتدا با استفاده از آمار توصيفى در قالب جدول و شاخصهاى عددى لند

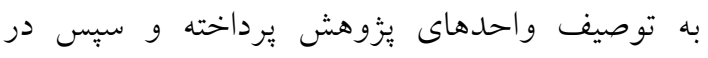

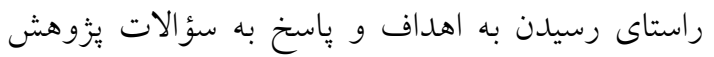

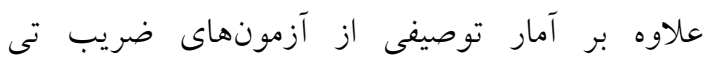

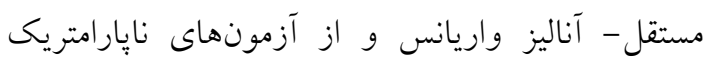
(آزمون كاى دو، آزمون من ويتنى) براى بررسى ارتباط إنسائ

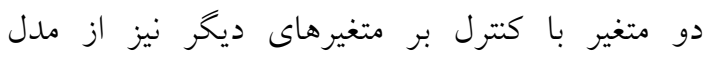

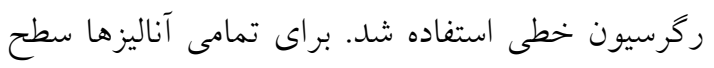

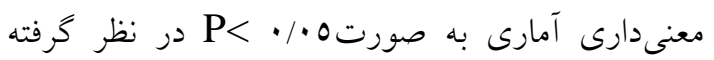

جدول شماره ا: شاخصهاى عددى كيفيت زندكى كارى و بهرهورى بر حسب مشخصات جمعيت شناختى در يرستاران شاغل در بخش اورزانس

\begin{tabular}{|c|c|c|c|c|c|c|c|c|}
\hline \multicolumn{3}{|c|}{ كيفيت زندگى كارى } & \multicolumn{3}{|c|}{ بهرهورى } & \multirow{2}{*}{ فراوانى } & \multirow{2}{*}{\multicolumn{2}{|c|}{ مشخصات جمعيت شناختى }} \\
\hline نتايج آزمون & انحر اف معيار & ميانگين & نتايج آزمون & انحراف معيار & ميانخين & & & \\
\hline$* " \mathrm{t} t=\cdot / \cdot r \mathrm{rdf}=1 \wedge \mathrm{V}$ & rY/20 & $\mid\{r / 7 \mid$ & $" \mathrm{t}=\cdot / \mu \mu \wedge$ df $=\backslash \wedge \vee$ & $1 \cdot 100$ & $Q T / V q$ & $(09 / \Gamma) \| 1 r$ & زن & \\
\hline $\mathrm{p}=\cdot / \mathrm{q} \vee$ & $r V / q I$ & $1 \varepsilon r / V 7$ & $\mathrm{P}=\cdot N r_{0}$ & Ir/Tr & $9 T / T$. & $(\varepsilon \cdot / V) V V$ & 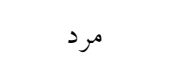 & جنسيت \\
\hline$* F=\cdot / \varepsilon r v$ & $r 7 / 97$ & $1 \varepsilon 0 / 7 \varepsilon$ & $\mathrm{F}=\cdot / / 1 \Gamma$ & $11 / 47$ & QY/AT & $(\Sigma 0) \wedge 0$ & YY-Yq & \\
\hline \multirow[t]{2}{*}{$\mathrm{p}=\cdot / \neg \varepsilon \vee$} & $r Y / \varepsilon \varepsilon$ & $|\varepsilon| / 7 r$ & $\mathrm{p}=\cdot / \wedge q 4$ & $11 / 11$ & $9 r / 7 \varepsilon$ & $(r v) v \cdot$ & rq-r. & سن، سال \\
\hline & $r \varepsilon / 9 q$ & $1 \varepsilon Y / 9 V$ & & $1 r / v q$ & $91 / \mathrm{V}$ & $(1 \Lambda) r \varepsilon$ & 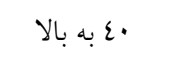 & \\
\hline$t=r / 9 \vee \varepsilon \quad d f=I \wedge V$ & TO/AV & $1 \varepsilon 7 / V r$ & "t $=-\cdot / 0 r r \quad d f=1 \wedge V$ & $11 / 79$ & $9 r / r 1$ & $(V V / \Lambda) \backslash \varepsilon V$ & متأهل & وضعيت \\
\hline $\mathrm{p}=\cdot / \cdot r$ & TN/TOO & $\mid r T / 9 V$ & $\mathrm{P}=\cdot 1090$ & $\mid r / \cdot \Lambda$ & $q \mu / \varepsilon$. & $(Y r / T) \varepsilon r$ & مجرد & تأهل \\
\hline$t=r / \backslash \vee \varepsilon d f=1 \wedge \vee$ & $r T / r \mid$ & $1 \varepsilon \varepsilon / 7 r$ & $* \mathrm{t}=-\cdot / \cdot 0 \Lambda \quad \mathrm{df}=1 \wedge \mathrm{V}$ & $11 / r q$ & $9 T / 0 \varepsilon$ & $(90 / \Gamma) \backslash \wedge$. & كارشناسى & تحصيلات \\
\hline $\mathrm{p}=\cdot / \cdot \mu_{1}$ & rT/rT & $\mid r \varepsilon / V V$ & $\mathrm{P}=\cdot / 90 \varepsilon$ & $\mid V / \varepsilon r$ & $9 T / V V$ & $(\Sigma / \Lambda) q$ & كارشناسى ارشد & \\
\hline$t=1 / 200 \quad d f=1 \wedge \mathrm{V}$ & $r T / A r$ & $1 \varepsilon \varepsilon / 1 \varepsilon$ & $\mathrm{t}=\cdot / 290 \quad \mathrm{df}=1 \wedge \mathrm{V}$ & $11 / 7 \varepsilon$ & $9 Y / 7 r$ & $(q \vee / \varepsilon) \backslash \wedge \varepsilon$ & مر كردش & شيفت كارى \\
\hline $\mathrm{P}=\cdot / l \varepsilon \vee$ & $r \cdot 107$ & $1 r v / \varepsilon$. & $\mathrm{p}=\cdot / \pi T^{\prime}$ & $1 \varepsilon / \mu$. & 9. & $(T / T) 0$ & صبح كار & \\
\hline$*_{t}=r / \Sigma r|d f=| \wedge V$ & $r 7 / 91$ & $1\{0 / 27$ & $\mathrm{t}=\cdot / \varepsilon \mid \vee \mathrm{df}=\backslash \wedge \mathrm{V}$ & $11 / 11$ & $9 r / 79$ & $(\Lambda V / \Gamma) 170$ & دريافت & اضافه كارى \\
\hline $\mathrm{P}=\cdot / \cdot 17$ & $r \varepsilon / 09$ & $|r| / r v$ & $\mathrm{p}=\cdot / \mathrm{TVV}$ & $1 \cdot / 91$ & $91 / 7 r$ & $(I T / V) T \varepsilon$ & فقدان دريافت & \\
\hline$t=r / r \circ 9 \quad d f=1 \wedge V$ & $r 0 / 90$ & וr/ & $t=-1 / 2 \varepsilon \quad d f=1 \wedge V$ & $11 / V \varepsilon$ & $91 / 77$ & $(70 / 7) \mid r \varepsilon$ & اجبارى & وضعيت \\
\hline $\mathrm{P}=\cdot / \cdot \cdot 1$ & $r y / \varepsilon q$ & $10 r / r 9$ & $\mathrm{P}=\cdot / 10$ & $11 / \varepsilon \wedge$ & $9 \varepsilon / T \varepsilon$ & $(r \varepsilon / \varepsilon) 70$ & اختيارى & كارى انتخاب ساعت \\
\hline $\mathrm{t}=1 / V \wedge r \quad \mathrm{df}=1 \wedge V$ & ro/ry & $1 \varepsilon \varepsilon / 9 \varepsilon$ & $" \mathrm{t}=r / \cdot \wedge \quad \mathrm{df}=1 \wedge \mathrm{V}$ & $|1 / \varepsilon|$ & $94 / 19$ & $(\Lambda \Lambda / \varepsilon) \backslash \mathrm{TV}$ & اشتغالدريكجا & اشتغال \\
\hline $\mathrm{P}=\cdot / \cdot v 7$ & ru/ru & $1 r \varepsilon / \cdot q$ & $P=\cdot / \cdot r q$ & $\mid r / A 0$ & NV/NT & $(11 / 7) r r$ & اشتغالدرجندجا & همزمان \\
\hline
\end{tabular}




\begin{tabular}{|c|c|c|c|c|c|c|c|c|}
\hline * $F=\cdot / r \varepsilon$ & rN/q. & $\mid \varepsilon Y / \cdot V$ & $* * F=\cdot / T \varepsilon$ & IT/rר & $9 \pi / \varepsilon 7$ & זד (ז/זr) & $1-\varepsilon$ & \\
\hline \multirow[t]{3}{*}{$\mathrm{P}=\cdot / 9\{\rceil$} & Tr/Or & $\mid\{r / 9 \mid$ & $P=\cdot / 9 \varepsilon\rceil$ & $9 / 19$ & $Q T / T V$ & $(T O / \varepsilon) \varepsilon \wedge$ & $0-9$ & سابقه كارى، \\
\hline & $r Y / 9 \Lambda$ & $120 / 10$ & & $I T / T$. & $9 T / 1 T$ & $(T \cdot / T) r_{q}$ & $1 \cdot-1 \varepsilon$ & سال \\
\hline & rT/A. & $\mid \varepsilon \varepsilon / \varepsilon \wedge$ & & $1 \pi / \cdot \varepsilon$ & $91 / v \varepsilon$ & $(T \cdot / T) r_{q}$ & 10 به بالا & \\
\hline$* F=\cdot / T Y Y$ & $r 0 / 90$ & $1 \varepsilon r / q r$ & $F=1 / \Gamma \varepsilon V$ & $11 / 49$ & QY/AV & $(O \Lambda / Y) 11$. & $1-\varepsilon$ & سابقه كارى \\
\hline \multirow[t]{3}{*}{$\mathrm{P}=\cdot / \wedge \wedge \mid$} & $r 9 / T_{0}$ & $1 \varepsilon 1 / 9 T$ & $\mathrm{P}=\cdot / r 71$ & $1 \cdot 117$ & $9 \varepsilon / V 1$ & $(T \cdot / T) r q$ & $0-9$ & در اورزانس، \\
\hline & $\mathrm{TV} / \mathrm{OV}$ & $\mid \varepsilon r / \cdot r$ & & $1 \varepsilon / T_{0}$ & $\wedge 9 / 7$. & $(10 / 9) r$. & $1 \cdot-1 \varepsilon$ & سال \\
\hline & $r \cdot 10 r$ & $1 \varepsilon 9 / 7$. & & $\Lambda / 1 \varepsilon$ & $19 / 0$. & $(T \cdot / T) r q$ & 10 به بالا & \\
\hline
\end{tabular}

يافتهها نشان داد، در نمونههاى مورد بررسى، از بين t=

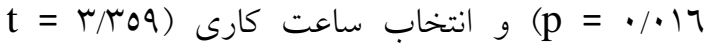

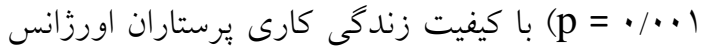
ارتباط معنى دار آمارى وجود داشت. در واقع يرستارانى كه اضافه كار دريافت مى كردند كيفيت زندگى بالاترى را گزارش كردند. انتخاب ساعت كارى نيز در برابر اجبارى بودن ساعت كارى، با كيفيت زندگى كارى بالاتر رابطه داشت (جدول شماره (). همانطور كه جدول شماره r نشان مىدهد كيفيت زندگى كارى در بعد زمينه كارى با ميانخين و انحراف معيار (

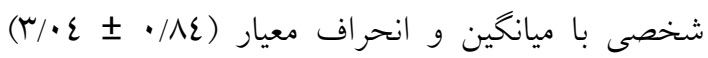
يايينترين نمره را در بين ساير ابعاد داشت. ميانخين و انحراف معيار نمره كل كيفيت زندگى كارى نيز (ع//.

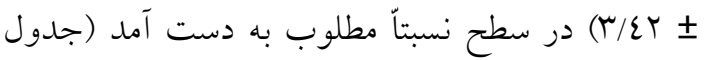

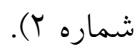

شاخصىهاى عددى بهروورى و كيفيت زندگى بر حسب مشخصات كارى در يرستاران شاغل در بخش اورزانس، در جدول شماره ا ارائه شده است. بين مشخصات جمعيتشناختى مورد بررسى، با كيفيت زندكى كارى برستاران، وضعيت تأهل ( p p p و تحصيلات (t=r/aV زندگى كارى ارتباط معنى دار آمارى وجود داشت. ميزان كيفيت زندگى كارى در برستاران متأهل از مجرد بيشتر بود. بيرستاران با سطح تحصيلات كارشناسى نيز از يرستاران با تحصيلات كارشناسى ارشد از كيفيت زندكى كارى بالاترى برخوردار بودند. از بين مشخصات كارى مورد بررسى، وضعيت اشتغال همزمان

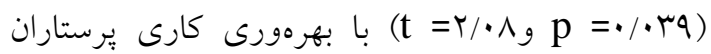

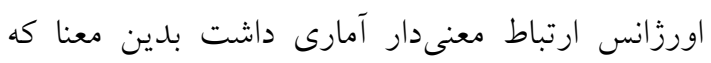
يرستارانى كه همزمان در جاى ديخرى نيز مشغول به كار بودند، نسبت به يرستارانى كه فقط در يك جا اشتغال داشتند، بهرهورى پيايينترى نشان دادند.

جدول شماره r: شاخص هاى عددى كيفيت زندَّى كارى يرستاران شاغل در بخش اورزانس

\begin{tabular}{|c|c|c|c|c|c|c|c|c|}
\hline \multicolumn{4}{|c|}{ مبناى ا تا 7} & \multirow{2}{*}{ انحراف } & \multirow[t]{2}{*}{ ميانخين } & \multirow[t]{2}{*}{ بيشينه } & \multirow[t]{2}{*}{ كمينه } & \multirow[t]{2}{*}{ كيفيت زندگى كارى و ابعاد آن } \\
\hline انحراف معيار & ميانخين & بيشينه & كمينه & & & & & \\
\hline$\cdot / \wedge \varepsilon$ & $r / \cdot \varepsilon$ & $0 / 79$ & 1 & O/A & $r|/ T|$ & rv & $\checkmark$ & زندگى شخصى \\
\hline$\cdot / 70$ & $r / 0$. & 0 & 1 & $7 / 01$ & $\mathrm{ro} / \cdot 1$ & 0. & $1 \cdot$ & جهارجوب كارى \\
\hline$\cdot / \mathrm{V} q$ & r/ON & $0 / 00$ & 1 & $10 / 9$. & $V I / V r$ & 111 & $r \cdot$ & زمينه كارى \\
\hline$\cdot / \wedge \varepsilon$ & $r / T$ & 7 & 1 & $\varepsilon / T r$ & $10 / 71$ & r. & 0 & جهانى \\
\hline$\cdot / 7 \varepsilon$ & $r / \varepsilon r$ & $0 / \cdot 0$ & $1 / 1$. & $r 7 / 91$ & $\mid \varepsilon r / T V$ & rIT & $\{7$ & كيفيت زندگى كارى (نمره كل) \\
\hline
\end{tabular}


|رارهاى غيرمبوط بخش، موجب مىشود از ميزان

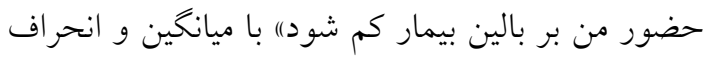

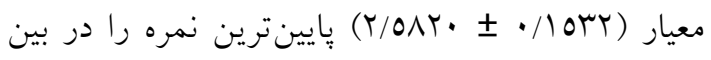

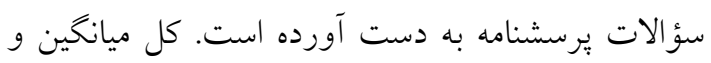

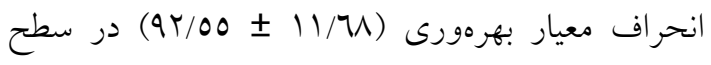
متوسط به دست آمد (جدول شماره ؟).
شاخص هاى عددى بهرهورى برستاران شاغل در بخش اورزانس در جدول شماره ب ارائه شده است. همانطور

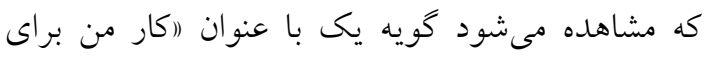

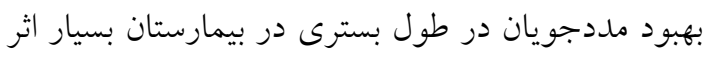

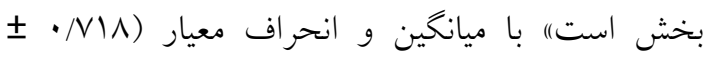

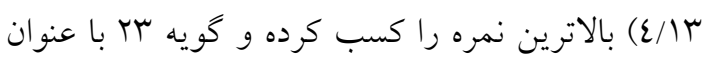

جدول شماره": شاخصهاى عددى بجرهورى يرستاران شاغل در بخش اورخانس

\begin{tabular}{|c|c|c|c|c|c|c|}
\hline \multicolumn{6}{|c|}{ فراوانى (درصد) } & \\
\hline ميانخين \ انحر افمعيار & كاملاًمخالفم & 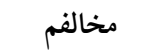 & فرقىندارد & 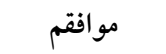 & كاملامّموافقم & \\
\hline \multirow[t]{2}{*}{$\varepsilon / \| r \pm \cdot N \mid$} & $r(1 / 7 r)$ & $\varepsilon(T / 19)$ & $\wedge(\Sigma / r \mu)$ & 1 ro $(77 / 11)$ & $29(10 / 91)$ & ا.كار من براى بهبود مددجويان در طول بسترى در \\
\hline & & & & & & بيمارستان بسيار اثر بخش است. \\
\hline \multirow[t]{2}{*}{$r / 7 V \pm \cdot / 90$} & $\varepsilon(Y / 19)$ & $r V(1 \varepsilon / \mu T)$ & $r r(I Y / Y V)$ & $1.9(0 V / N T)$ & $r 7(|r / \Lambda|)$ & ז.با مراقبت ارائه شده، مددجو كليه آموزشهاى \\
\hline & & & & & & مورد نياز بعد از ترخيص را دريافت نموده است. \\
\hline$r / 77 \pm 1 / 1 \Lambda$ & $07(Y 9 / 7 \varepsilon)$ & $7)(r Y / r V)$ & $r r(17 / 9 r)$ & $\mu(1 \mathrm{~V} / 07)$ & $V(r / N T)$ & "ا.كار من در ارتقاء سازمان جندان تأثيرى ندارد. \\
\hline \multirow[t]{2}{*}{$r / \mu q \pm 1 / \varepsilon r$} & $r(1 T / 9 r)$ & $r 0(1 T / r \varepsilon)$ & $11(11 / 19)$ & $7 \cdot(\Gamma \mid N T)$ & $01(Y V / \cdot T)$ & ع.كار من نسبت به حقوق دريافتىام براى سازمان از \\
\hline & & & & & & نظر اقتصادى بسيار باصرفه است. \\
\hline \multirow[t]{2}{*}{$\varepsilon / \cdot 0 \pm \cdot / 19$} & $0(Y / 7 Y)$ & $V(\Gamma / V T)$ & $r \cdot(1 \cdot / 79)$ & $91(01 / 99)$ & $09\left(\Gamma_{1 / T \cdot}\right)$ & 0با امكانات موجود حداكثر توان خود را در ارائه \\
\hline & & & & & & مراقبتى با كيفيت به كار گرفتهام. \\
\hline \multirow[t]{2}{*}{$r / N q \cdot \pm \cdot / q \varepsilon$} & $7(r / Y O)$ & $\operatorname{lV}(9 / \cdot 9)$ & $r r(11 / 77)$ & $1.9(0 V / N T)$ & ro $(1 \mathrm{~N} / \mathrm{OV})$ & 7.مراقبت از بيمار در بخش ما در حد يكى مراقبت \\
\hline & & & & & & حرفهاى است. \\
\hline \multirow[t]{2}{*}{$r / 7 \mu \pm 1 / 1}$. & $\wedge\left(\varepsilon / \mu^{\mu}\right)$ & $M(1 T / \Sigma T)$ & $r \cdot(1 \cdot / 79)$ & $9 r(\Sigma q / r \wedge)$ & $\mathrm{rV}(19 / \mathrm{TV})$ & Vار من در سازمان آنقدر حرفهاى است كه فرد \\
\hline & & & & & & ديخرى جز يك برستار كارشناس،نمىتواندانجامدهد. \\
\hline \multirow[t]{2}{*}{$r / 9 V \pm 1 / 1 \varepsilon$} & $1 \wedge(9 / 0 Y)$ & $O \varepsilon(Y \wedge / 7 \Gamma)$ & rV $(19 / 77)$ & $77(\Gamma \varepsilon / 9 \vee)$ & $1 \varepsilon(V / \varepsilon r)$ & ^.كار روتينوار است و از يكسرى وظايف غير \\
\hline & & & & & & مربوط به مراقبت مستقيم از بيمار تشكيل شدهاست. \\
\hline \multirow[t]{2}{*}{$\varepsilon / / r \pm \cdot / \wedge \cdot$} & $\varepsilon(T / 19)$ & $r(1 / 1 \wedge)$ & $r \cdot(1 \cdot / 79)$ & $1 \cdot \varepsilon(00 / \cdot 1)$ & $09(\Gamma \backslash / K \varepsilon)$ & 9.كار من در تيم درمانى به عنوان كارى مهم جهت \\
\hline & & & & & & بهبود بيمار به شمار مىرود. \\
\hline \multirow[t]{3}{*}{$\varepsilon / \cdot r \pm \cdot / \wedge q$} & $V(r / V \varepsilon)$ & $0(Y / T V)$ & $17(1 / 01)$ & $11 \cdot(O N / T r)$ & $01(Y V / \cdot Y)$ & • ا. در كارم راه و روش درست و اصولى را بر مى \\
\hline & & & & & & كزينم حتى اخر نتايج دشوارى در كارسازمانى براى \\
\hline & & & & & & من داشته است. \\
\hline \multirow[t]{3}{*}{$r / 9 T \pm \cdot / 10$} & $\varepsilon(Y / 19)$ & $11(0 / \wedge r)$ & $r 1(11 / 19)$ & $11 \varepsilon(7 \cdot \mu V)$ & $r q(T \cdot / T \varepsilon)$ & 11 1.عملكردهاى اخلاقى مربوط به كارم را مىشناسم \\
\hline & & & & & & و قادرم همه موارد اخلاقى مربوط به كارم را \\
\hline & & & & & & رعايت كنم. \\
\hline$r / V V \pm \cdot / \Lambda 1$ & $r(1 / 7 r)$ & $\|(7 / 9 \varepsilon)$ & $\mu_{1}(1 T / \varepsilon r)$ & $119(7 \pi / .0)$ & $r r(I T / T V)$ & T I.كارم به كونهايست كهمىتوانمبهقو انينمتعهدباشم. \\
\hline$r / 0 r \pm 1 / \cdot r q$ & $1 \cdot(0 / \Gamma)$ & $r 7(\mid r / \Lambda 1)$ & $T V(\mid \varepsilon / \mu)$ & $1.7(07 / 17)$ & $r \cdot(1 \cdot / 79)$ & ז ا.در كارم مىتوانم كاملاً عدالت را رعايت كنم. \\
\hline \multirow[t]{2}{*}{$\Gamma / \wedge \varepsilon \pm \cdot / \wedge \varepsilon$} & $r(1 / 7 r)$ & $1 \pi(7 / 9 \varepsilon)$ & $r \wedge(|\varepsilon / \Lambda|)$ & $11 \%(09 / \mu \mathrm{V})$ & r (1V/07) & ع ا.در مورد كارم قادرم بهترين راه را انتخاب كنم و \\
\hline & & & & & & آن را انجام دهم. \\
\hline$r / \Lambda \neg \pm \cdot / \Lambda \mu$ & $7(r / r q)$ & $7(r / Y q)$ & $T V(\mid \varepsilon / \mu)$ & $119(7 \pi / .0)$ & $M(1 T / \varepsilon r)$ & 10.نتايج حاصل از كارم را ارزيابى مى كنم. \\
\hline$r / 07 \pm \cdot / 9 \varepsilon$ & $9(\varepsilon / 17)$ & $10(V / 94)$ & $\varepsilon \varepsilon(T \mu / \uparrow)$ & $1 \cdot r(0 \varepsilon / 0 r)$ & $1 \wedge(9 / 0 Y)$ & 7 ا.بلدون اينكه وادار شومبهمافوق خودياسخكوهستم. \\
\hline
\end{tabular}




\begin{tabular}{|c|c|c|c|c|c|c|}
\hline$r / 91 \pm \cdot / 91$ & $\wedge(\varepsilon / r \mu)$ & Ir $(T / \mu)$ & $\operatorname{lV}(9 / \cdot 9)$ & $1 \cdot \varepsilon(00 / \cdot 1)$ & $\varepsilon \wedge(T O / \varepsilon r)$ & نظارت انجام مىدهم. و و مسئوليت هاى خود را حتى بدون \\
\hline$r / V \Lambda \pm \cdot / 9 r$ & $r(1 / \pi r)$ & $r \cdot(1 \cdot / 79)$ & $r V(1 \varepsilon / \mu)$ & $1 \cdot\{(00 / \cdot 1)$ & ro $(\mathrm{IN} / \mathrm{OV})$ & 11.دائماً جهت رشد و اعتلاى حرفهايم تلاشى كنم. \\
\hline$r / 0 \wedge \pm 1 / \cdot 1$ & $\wedge\left(\Sigma / \Gamma^{\mu}\right)$ & rT $(11 / 7)$ & $\mu q(T \cdot / T \varepsilon)$ & $q \Gamma\left(\sum q / \Gamma \wedge\right)$ & $T V(\mid \varepsilon / \mu)$ & و.. به روز أكاهى و دانش خود را با مطالعه كتب، مجلات \\
\hline$r / q \cdot \pm \cdot / \Lambda \cdot$ & $r(1 / / \varepsilon)$ & $1 \cdot(0 / \pi)$ & $r 9(10 / \pi)$ & $11 r(09 / \mathrm{rV})$ & rq $(19 / \cdot)$ & •r.به خوبى در مهارتهاى مورد نياز كارمتسلطدارم. \\
\hline$r / \wedge \varepsilon \pm \cdot / \Lambda r$ & $r(1 / \pi r)$ & IT (T/T) & $r \wedge(|\varepsilon / \Lambda|)$ & $110(7 \cdot / 1)$ & $\mu(1 T / \varepsilon r)$ & اY.حداكثر كار را در حداقل زمان انجام مىدهم. \\
\hline$r / r \mu \pm 1 / \cdot 11$ & $q(\varepsilon / A r)$ & $0 .(Y 7 / 07)$ & $r \varepsilon(1 / / \cdot 9)$ & $\Lambda \cdot(\varepsilon Y / \mu \wedge)$ & $17(1 / 01)$ & 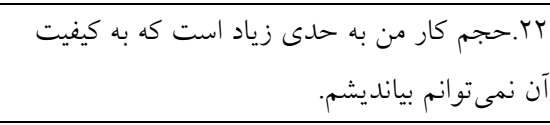 \\
\hline$r / 0 \Lambda \pm \cdot / 10$ & $11(0 / \wedge r)$ & $\mu_{\Lambda}(Y \cdot / \Lambda \Lambda)$ & $\mu r(1 T / 9 T)$ & $V V(\varepsilon \cdot / V\urcorner)$ & $M(1 T / \varepsilon r)$ & 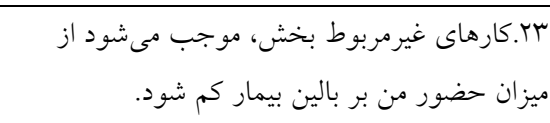 \\
\hline$r / 9 \wedge \pm \cdot / \Lambda 1$ & $r(1 / 7 r)$ & $7(r / r q)$ & $r \wedge(|\varepsilon / \Lambda|)$ & $1.7(07 / 17)$ & $\varepsilon\rceil(Y \varepsilon / \Gamma 0)$ & عَّ بـ براى من كيفيت كار اهميت بيشترى از اتمام \\
\hline$\varepsilon / \Gamma \wedge \pm \cdot / V V$ & $r(1 / / \varepsilon)$ & $\varepsilon(Y / 19)$ & $1 \pi(7 / 9 \varepsilon)$ & $q \cdot\left(\sum V / 7\right)$ & $\Lambda \cdot(\varepsilon Y / \Lambda \Lambda)$ & 0Y.نسبت به كارم احساس تكليف و تعهد دارم. \\
\hline \multicolumn{7}{|c|}{ ميانخين / انحراف معيار 11/Th 9Y/00 } \\
\hline
\end{tabular}

ها در كنار تجهيزات، داروها و تكنولوزى، در ميزان بهرهورى مؤثرند. تغيير و تحول در اين عوامل در سالهاى اخير منجر به بهبودى ميزان بهرهورى در

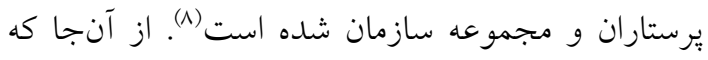

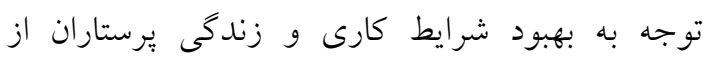

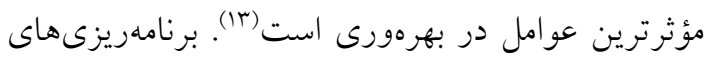

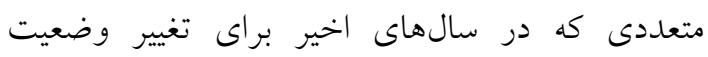

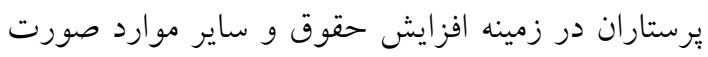

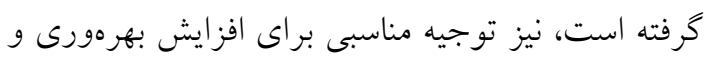
بهرهورى متوسط در يرستاران است. هم اكنون استانداردهاى دقيقترى نيز در رابطه با ارتقاى خدمات يرستارى اورزانس مشخص شده كه شامل تشخيص، برنامهريزى، اجرا و ارزشيابى مراقبتهاى يرستارى، استاندارهاى حرفهاى، شامل ثبت و ضبط اطلاعات بيماران و ارائه مراقبت با كيفيت در جهارجوب إنلاق حرفهاى است كه باعث مى شود، يرستاران تصور روشن و دقيق از انتظارات سيستم داشته و بتوانند خود را با بال اين انتظارات هماهنگ كنند. طراحى و بيان اين شاخصهاى عينى در ميزان تعهد و علاقهمندى

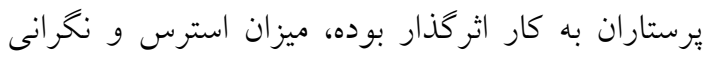

\section{بحث و نتيجه تيرى}

يافتهاى اين مطالعه نشان داد به طور كلى ميانخين بهرهورى برستاران در سطح متوسط قرار داشت. نتايج

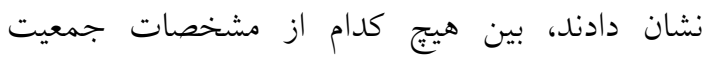
شناختى مورد بررسى با بهرهورى كارى برستاران ارتباط هيج

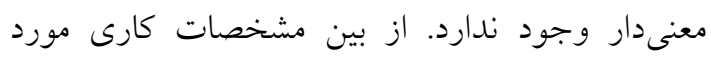

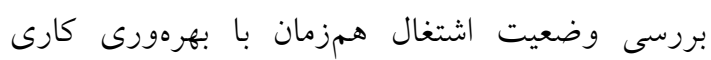

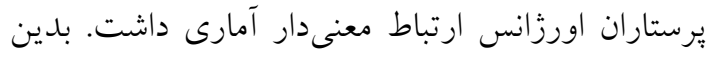

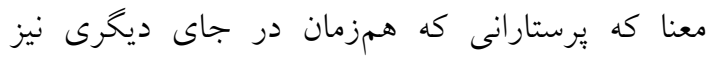

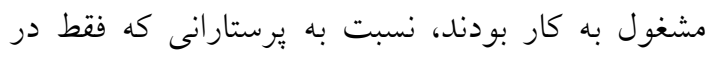
يكى جا اشتغال داشتند، بهرهورى بايين ترى نشان دادند.

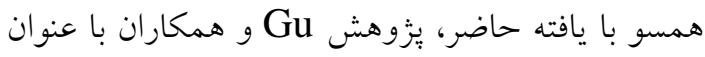
رشد بهرهورى يرستاران ماهر در شرايط مراقبتهاى تماى ويزه يس إز سانحه، بهرهورى يرستاران بين سالهاى

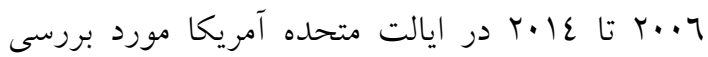
قرار كَفته بود كه بالاتر از متوسط كزارش شد (•م). دوستمحمدى و همكاران نيز يرستاران بيمارستانهاى

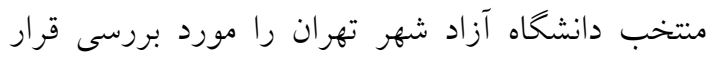

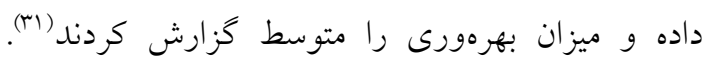

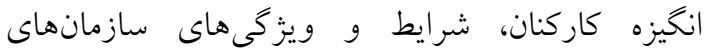
سلامت، نحوه تقسيم كار و كيفيت مديريت اين سازمان 
يرستاران آن نقش دارد. تفاوت در حوزههاى نام برده در محيطهاى مورد يُزوهش يافتهاى متفاوتى را ارائه مى دهل. يافتهها نشان دادند كيفيت زندكى كارى يرستاران در

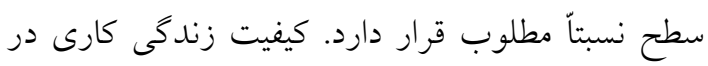
بعد زمينه كارى بالاترين و در بعد جهانى هايينترين نمره را در بين ساير ابعاد داشت. از طرفى بين مشخصات جمعيتشناختى مورد بررسى با كيفيت

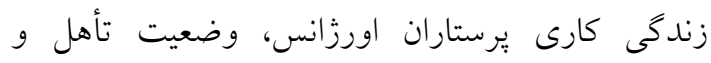
تحصيلات با كيفيت زندكى كارى ارتباط معنىدار آمارى داشت. ميزان كيفيت زندگى كارى در برستاران

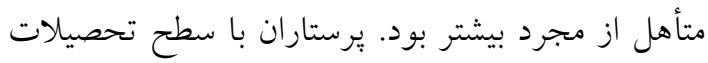

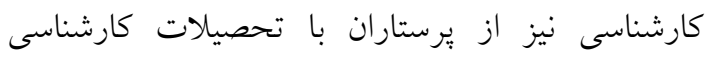
ارشد از كيفيت زندگى كارى بالاترى برخوردار بودند.

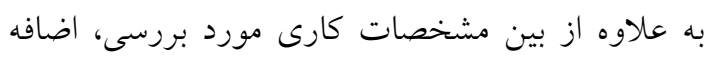
كارى و انتخاب ساعت كارى با كيفيت زندگى كارى يرستاران اورزانس ارتباط معنىدار آمارى داشتئن يرستارانى كه اضافه كارى دريافت مى كردند كيفيت زندگى بالاترى را كزارش كردند. انتخاب ساعت كارى لئى

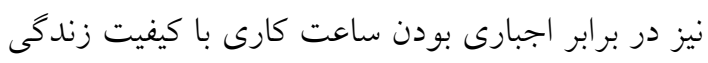
كارى بالاتر رابطه داشت.

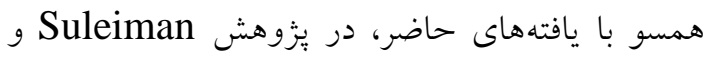

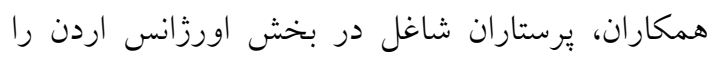

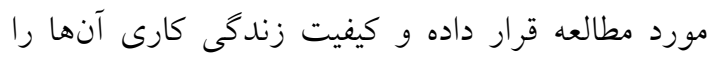

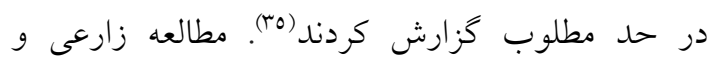
همكاران با هدف تعيين كيفيت زندكى كارى و تمايل به ترى شغل كاركنان در يكى از بيمارستانهاى آموزشى درمانى دانشخاه علوم يز شكى تهر بهان نيز كيفيت زندگى كارى يرستاران را در سطح متوسط به بالا نشان داد ("iT). از ديدكاه Walton حقوق و مزايا، محيط فيزيكى و غيرفيزيكى كار، ساعات كارى و امكانات رفاهى در

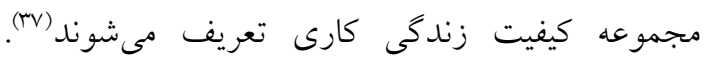
بنابراين بهبود عوامل نام برده قطعاً مى تواند در ارتقاء
آنها را كاهش داده و در نتيجه در بهبود بهروورى آنها مؤثر است. برخى يزوهشها نيز يافتهاى مغاير با مطالعه حاضر را

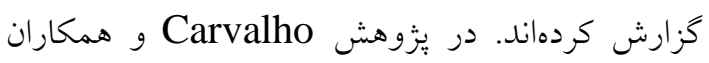
كه به منظور بررسى ارتباط بين افت بهرهورى كاركنان

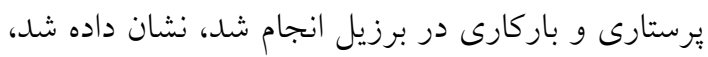
بهرهورى يايينتر از متوسط بوده و بخشى از بهرهورى به دلايل متعدد در سازمان از بين مىرود. به اين معنى

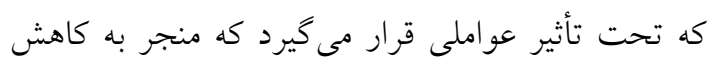

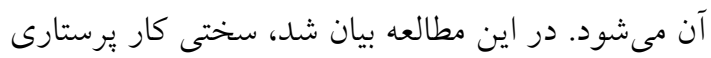
و تعداد نيروى كم نسبت به خدماتى كه بايد ارائه دهند،

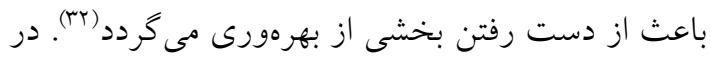

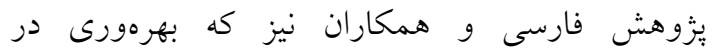
يرستاران بيمارستانهاى آجا در شهر تهر ان سنجيده شد، بهرهورى يرستاران در سطح هايينتر از متوسط قرار لهار

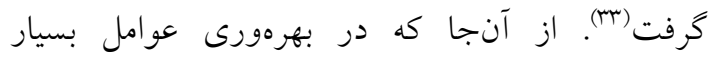
متعددى نقش دارند، تفاوت در هر كدام از عوامل در

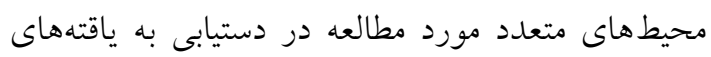

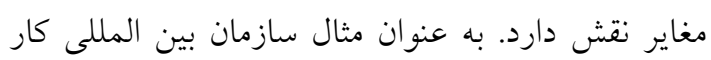

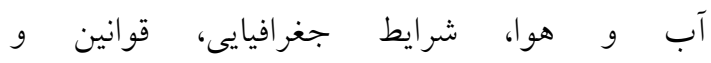

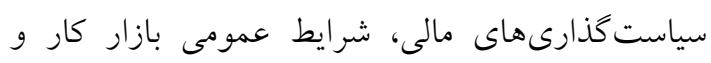

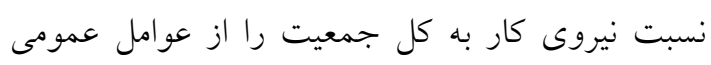

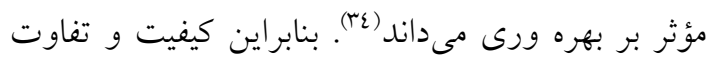
در اين عوامل در محيطهاى مختلف بهرهورى متفاوتى بهى بهري

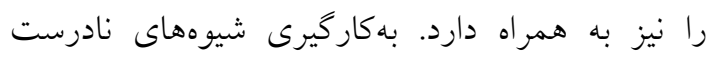
مديريت، حمايت نكردن از كاركنان برستارى و اهميت

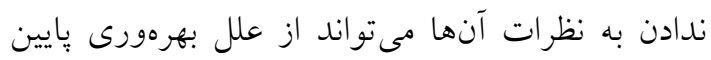

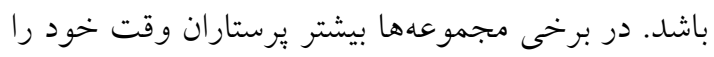

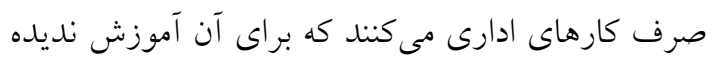

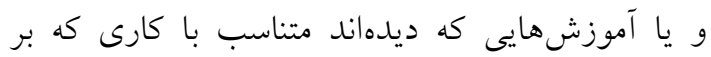

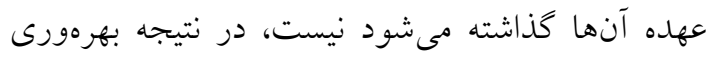
آنها كاهش مىيابد. محيط بيمارستان شامل فضاى

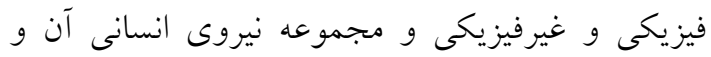
مديريت بيمارستان نيز در بهرهورى نيروى انسانى و 
مطالعات متعددى يافتههايى مشابه با يافته حاضر را

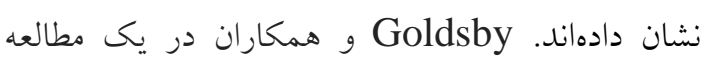
توصيفى اشتغال همزمان را با بهرهورى كمتر مرتبط دانسته و بيان كردند، اشتغال همزمان و افزايش ساعت بهر

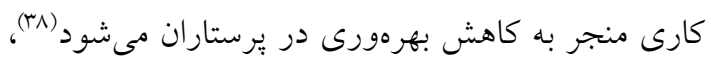

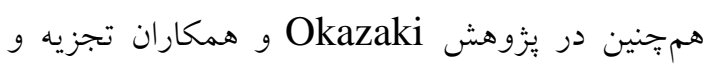

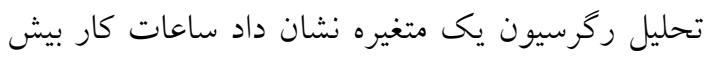
از •ع تا •0 ساعت در هفته و بيشتر از •0 ساعت در هفته به طور معنى دارى با بهرهورى كارى يرستاران در ارتباط است (هa). زمانى كه يرستاران همزمان در جايى ديخر نيز شاغل

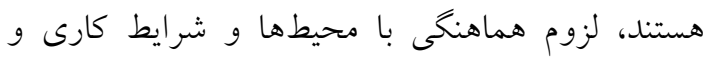

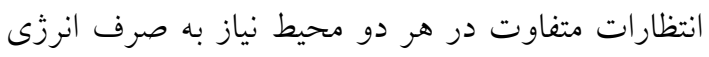
روانى و جسمانى بيشترى دارد. در نتيجه فشار كارى

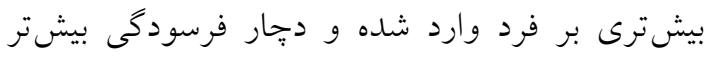

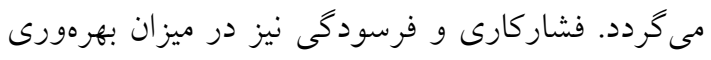

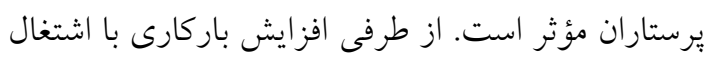

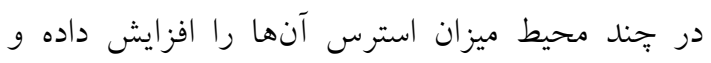

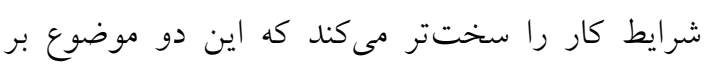

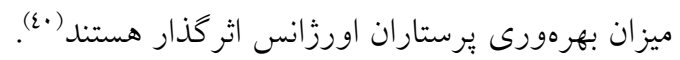

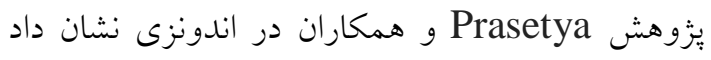
بين بهرهورى يرستاران با تجربه كارى و جنسيت رابطه

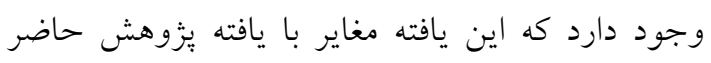

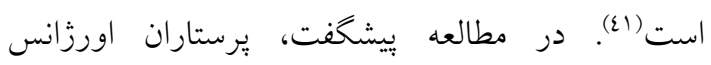

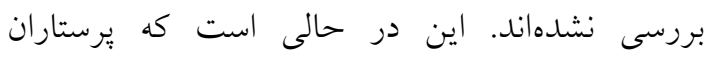

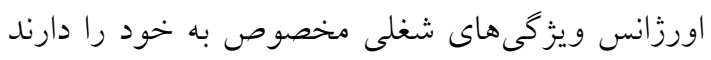

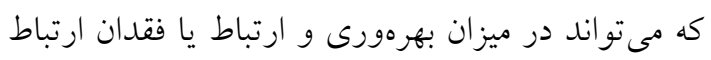

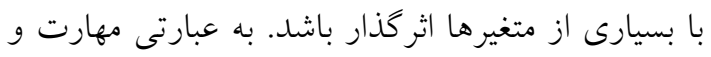
توانايى انجام كار در شرايط بحرانى از الزامات كار

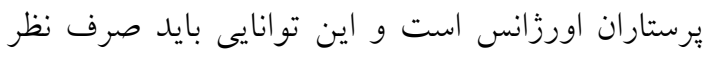

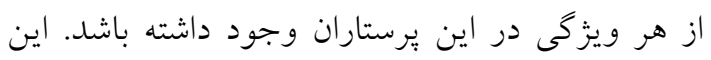

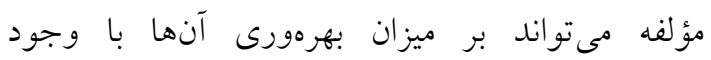
تفاوتهاى مختلف جمعيتشناختى مؤثر باشد.
كيفيت زندگى كارى يرستاران نقش داشته باشد. هم اكنون نيز توجه به كيفيت زندگى كارى نيروى انسانى و

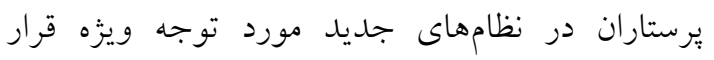

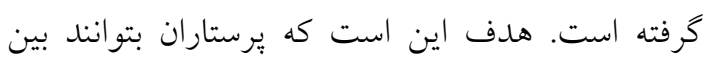
زندكى كارى و شخصى خود تعادل برقرار كنند تا ميزان كيفيت زندگى كارى آنها نيز افزايش يابد (19). ناهمسو با مطالعه حاضر، نصيرزاده و همكاران كيفيت زندكى كارى يرستاران را در سطح كم كزارش كردند.

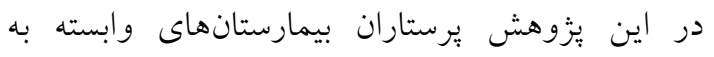

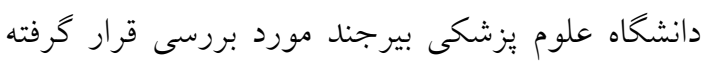

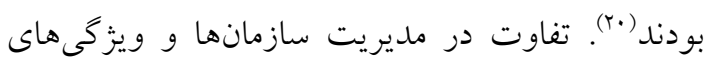
نيروى انسانى شاغل يعنى يرستاران مىتواند بر ميزان كيفيت زندكى در مجموعههاى مختلف اثر كذار باشد و باعث كيفيت زندگى متفاوت در سازمانهاى متعدد

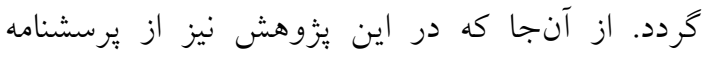

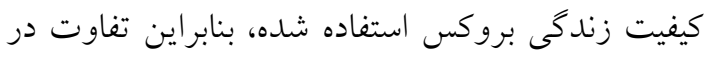

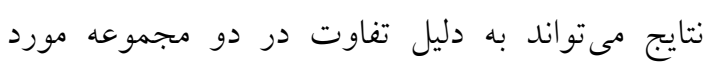

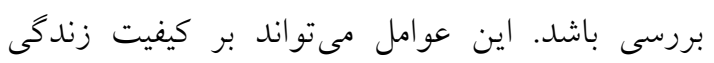

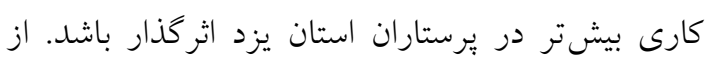
طرفى ميزان كيفيت زندكى كارى به عملكرد كل سازمان

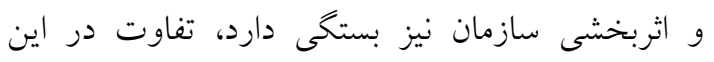
زمينه در محيطهاى مورد مطالعه مى تواند توجيه كننده

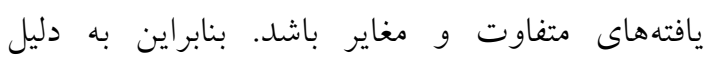

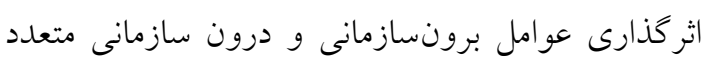

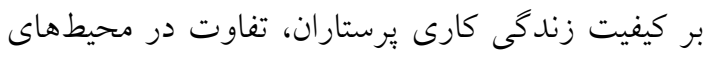
مورد يزوهش در كسب يافتههاى متفاوت مؤثر است.

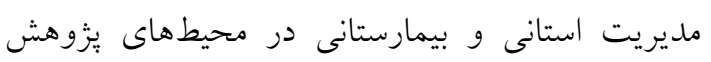
متفاوت بوده و نتايج متفاوتى نيز حاصل مى شوده.

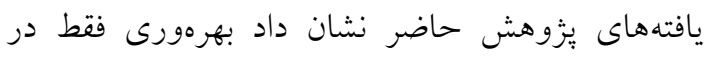

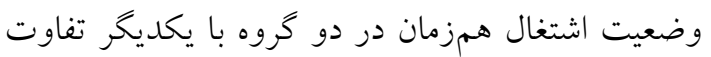
معنادار داشته است. به اين معنى كه ميزان بهرهورى در

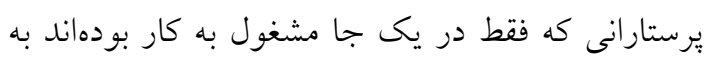

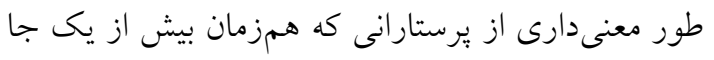
اشتغال داشته|ند، بيشتر بوده است. برستارسي 
ويزه هنكامى كه محيط كار آنها انتظارات آنها را برآورده نكند (20) هم جنين كيفيت زندكى كارى در يرستاران دريافت

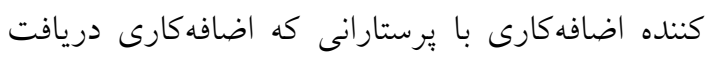

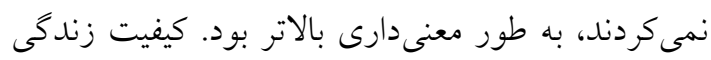

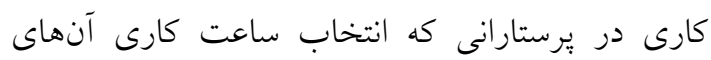
اختيارى بود نيز به طور معنى دارى بالاتر از يرستارانى دهاب

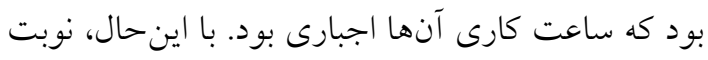
كارى، اشتغال همزمان، تجربه كارى و تجربه كار در اورزانس با كيفيت زندگى كارى ارتباط معنىدار نداشت. يافتهاى حاضر در يزّوهش هاى متعددى مورد

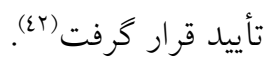
در رابطه با ارتباط افزايش كيفيت زندكى كارى با انتخاب ساعت كارى مىتوان جنين استدلال كرد كه حق انتخاب باعث مىشود افراد در برنامهريزى براى امور خود حق انتخاب بيشترى داشته و با دغدغه كمتر وارد محيط كار خود در زمانهايى كه خود انتخاب

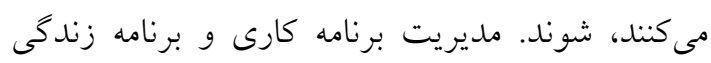

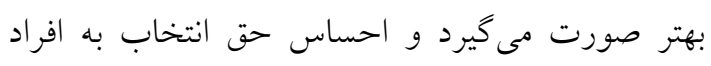

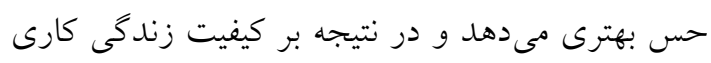
آنها اثر كذار است. دريافت اضافهكارى نيز افراد را راز داز

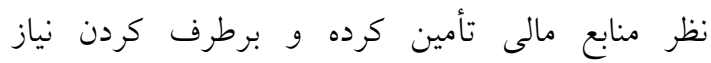

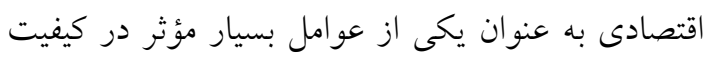

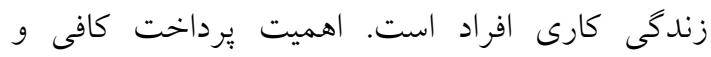
مناسب تا اندازهاى است كه به عنوان يكى از ابعاد مهم

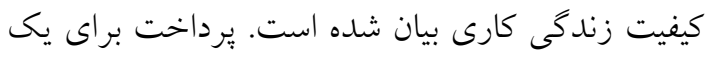

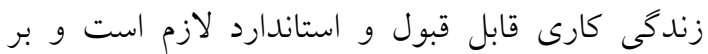

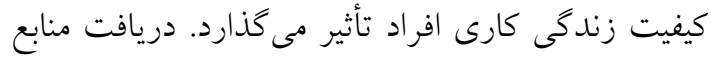
مالى بيشتر در قالبهاى متعدد مانند اضافه كارى بر كيفيت زندكى شخصى يرستاران نيز اثر كذار است. اين

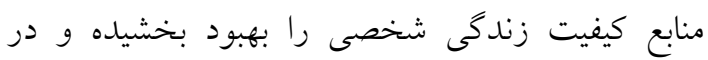
نتيجه كيفيت زندكى كارى را نيز افزايش مىدهد.

ناهمسو يا يافتهاى حاضر، يُزوهش Fernandes و همكاران نشان داد، بين كيفيت زندكى كارى بـ برستاران
يافتهاى يزووهش حاضر نشان داد، كيفيت زندكى كارى

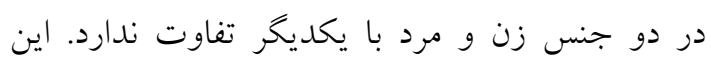

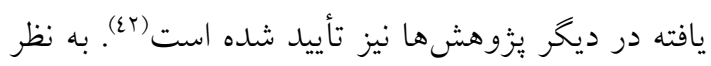

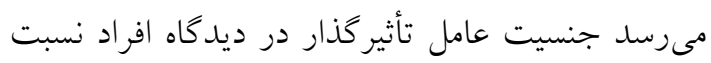
به كيفيت زندكى كارى آنان نباشد.

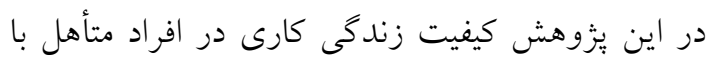

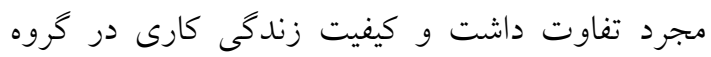

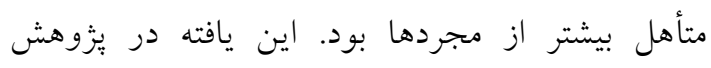

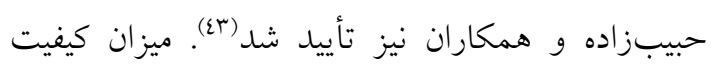

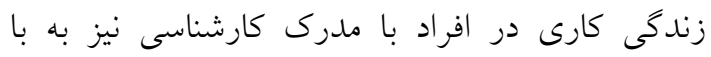
كيفيت زندىى كارى در برستاران با مدرى كارشناسى ارشد تفاوت معنىدار داشت. به اين معنى كه كيفيت زندكى كارى يُرستاران با مدرى كارشناسى از بِرستاران

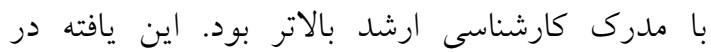

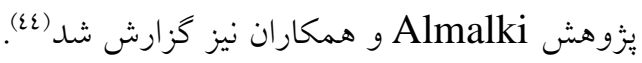

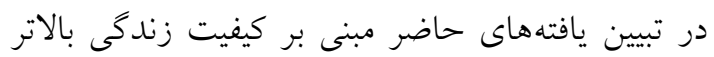

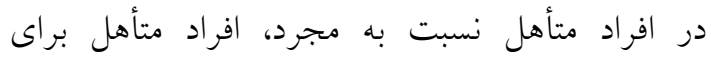

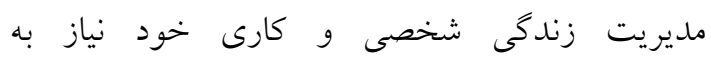

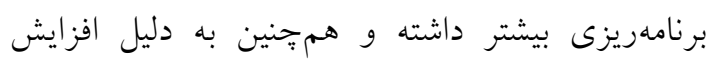

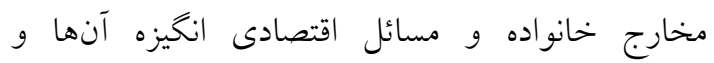
علاقهمندىشان براى كار افزايش مى يابد. لزوم مديريت

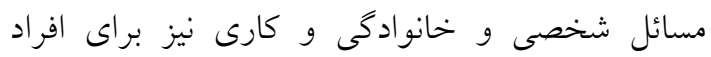
متأهل بيشتر است. اين موارد باعث مى مشود افراد متأهل

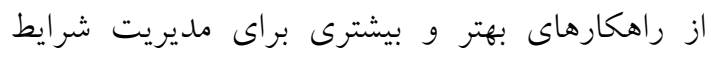
استفاده كرده و در نتيجه كيفيت زندكى كارى بالاترى

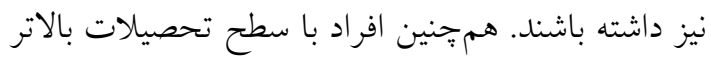
انتظارات و توقعات بيشترى از محيط كارى و شرايط كارى خود دارند و همجنين انتظارات اطرافيان در محيط كار نيز به دليل سطح تحصيلات بالاتر از آنها

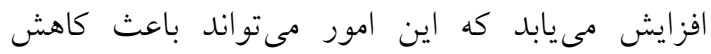

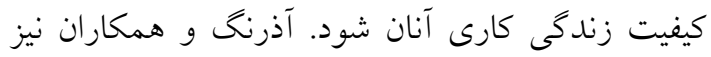

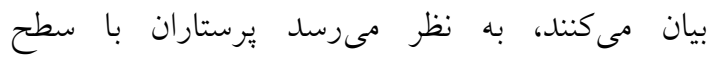
تحصيلات بالاتر انتظارات بيشترى از زندكى كارى خود

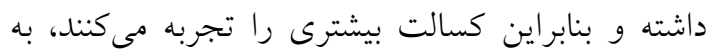


بهبود بهروورى و كيفيت زندكى كارى يرستاران اورزانس باشد. شناسايى موانع بهرودورى و و كيفيت

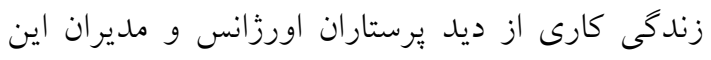

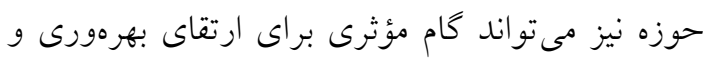

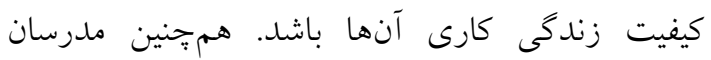

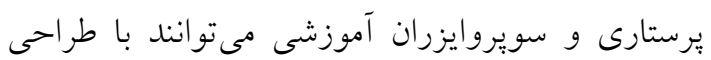

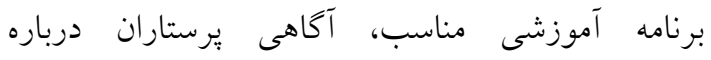
بهرهورى و كيفيت زندكى كارى را بهبود بخشيده و براني راهبردهاى مؤثر در ارتقاى آنها را آموزش دهند. مديران يرستارى نيز با برقرارى ارتباط مؤثر و ارضاى نيازها و خواستههاى يرستاران اورزانس، مىتوانند در برد بهبود بهرهورى و كيفيت زندكى كارى نقش داشته باشند. با توجه به اينكه آكاهى نقش مهمى در ايجاد نكرش مثبت و در نتيجه رفتار دارد، لازم است مديران

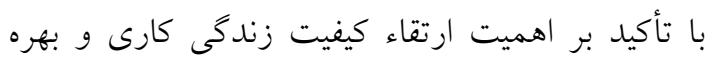
ورى، يرستاران را در راستاى بهبود بخشيدن به شرايط

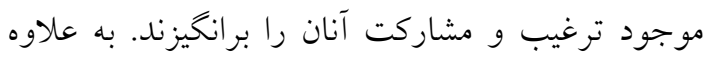

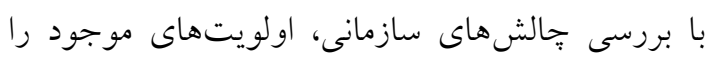
تعيين و جهت برنامههاى آموزشى و مديريتى را بر آن آن

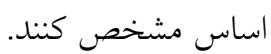

در زمان نمونه كيرى مطالعه حاضر، بيمارى Covid-19

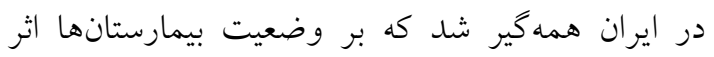

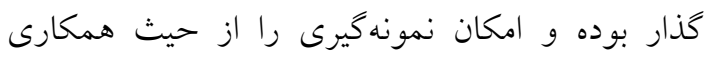

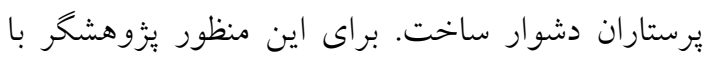
مراجعات متعدد تلاش كرد در زمان مناسب موفق به جلب همكارى يرستاران شود. اين يُزوهش محدود به يرستاران اورزانس شاغل در بيمارستانهاى وابسته به دانشخاه علوم يزشكى شهيد

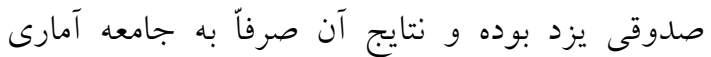
مذكور قابل تعميم است، لذا در تعميم آن به ساير مراكز

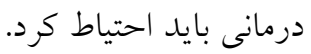

تعارض منافع: هيج تعارض منافع توسط نويسندكان بيان نشده است.
در گروههاى سنى و سابقه كارى مختلف تفاوت وجود

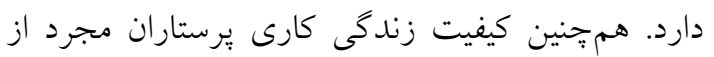

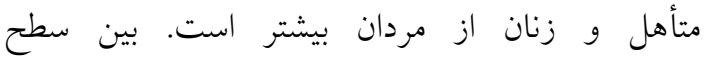

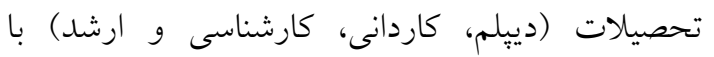

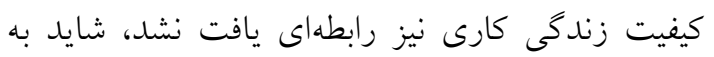

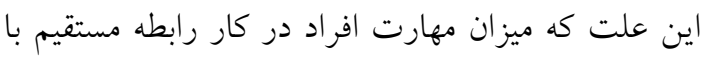

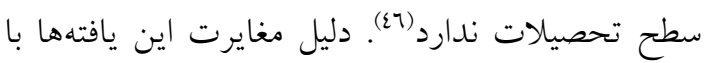
يافتهاى يُزوهش حاضر مىتواند به دليل تفاوت در

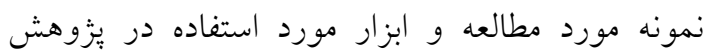

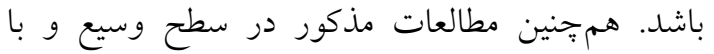
تعداد نمونه بالا بوده كه مىتواند دليل ارائه يافتههاى متفاوتى با يُزوهش حاضر باشد.كذر زمان و تغيير در نظام سلامت در جند سال اخير مىتواند متغيرهاى بسيارى در حوزه كيفيت زندكى كارى يرستاران را

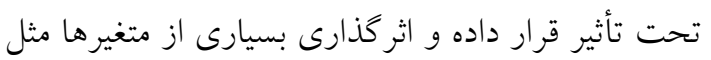

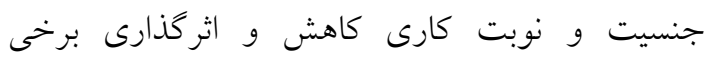
متغيرها افزايش يابد. با توصيف اين دو متغير مهم در يثزوهش حاضر يابر

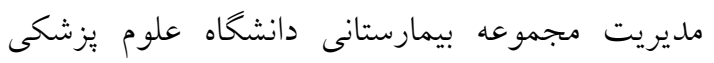
شهيد صدوقى يزد از وضعيت بهرهورى و كيفيت

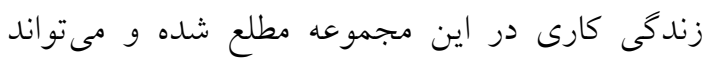
شناخت دقيقى از وضعيت مجموعه داشته باشد. يزّوهش حاضر هم جِنين نشان داد برستاران با اشتغال در دو جا ميزان بهرهورى بايينترى دارند. اين يافته

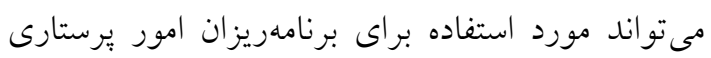

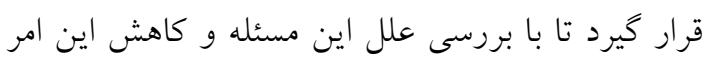
ميزان بهرهورى يرستاران را افزايش دهند. همجينين مشخص شد صرف ارتقاى تحصيلى بر اساس مدرى

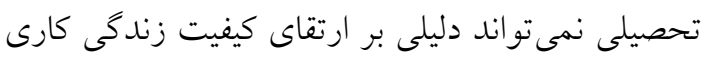
باشد. آكَاه سازى يرستاران از اين يافتهها مى تواند اين متغيرها را بهبود بخشيده و منجر به افزايش رضايت يرستاران و بهرهورى سازمان كردد.

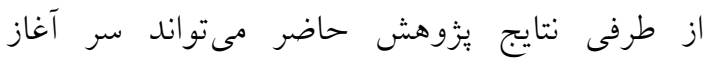

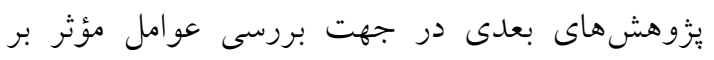



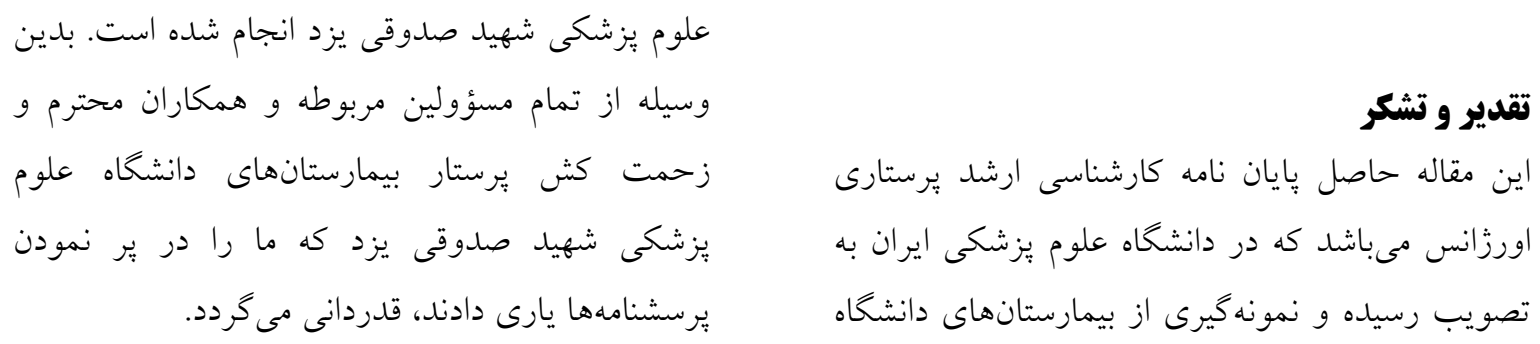

\section{References}

1. Hasandoost F, Ghanbari Khanghah A, Salamikohan K, Kazemnezhad Leili E, Norouzi Pareshkouh N. Prioritization of general clinical competence indicators from nurses' view employed in emergency wards. Journal of holistic nursing and midwifery. 2015;25(4):53-63. [Persian]

2. Gurney D, Gillespie GL, McMahon MP, Kolbuk ME. Nursing Code of Ethics: Provisions and Interpretative Statements for Emergency Nurses. J Emerg Nurs. 2017;43(6):497-503.

3. Emergency Nurses Association. Emergency Nurses Association Position Statement: Collaborative and Interdisciplinary Research. J Emerg Nurs. 2006;32(5):385-7.

4. Mollaoğlu M, Çelik P. Evaluation of emergency department nursing services and patient satisfaction of services. J Clin Nurs. 2016;25(19-20):2778-85.

5. Hosseini Nassab D, Aghi Niya AT. A study of the relationship between the quality of the staff work life with their productivity in Tabriz. Journal of Instruction and Evaluation. 2011;4(15):25-46. [Persian]

6. Boedker C, Mouritsen J, Guthrie J. Enhanced business reporting: international trends and possible policy directions. J Human Resource Cost Accoun. 2008 Apr 4.

7. Peyrovani L, Zade M A. The relationship between professional ethics and the quality of working life and employee productivity Mother and Child Hospital in Shiraz. Islamic Azad University, Marvdasht Branch; 2014. [Persian]

8. Rashad M. Improving Health Worker Productivity and Performance in the Context of Universal Health Coverage: the Roles of Standards, Quality Improvement, and RegulationFinal Draft. USAID, Applying Sci to strenghthen Improv Syst. 2014.

9. Mahdiyan S, Ferdosi M, Rafiei S, Askari R. Development of a Productivity Assessment Tool for Hospital Settings in Iran: A Delphi Study. Evidence Based Health Policy, Management and Economics. 2019;3(2):75-86.

10. Safiri S. The Study of the Relationship between Quality of Working Life and Hardiness in Amin Hospital of Isfahan. Ministry of Science, Research and Technology ALGHADIR NonGovernmental and Private Higher Education Institution. 2016. [Persian]

11. Cutler DM. Nursing Our Way to Better Health. JAMA. 2019;322(11):1033-4.

12. Hunt PS, Hartman D. Meeting the measurements of inpatient staffing productivity. Nurs Manag. 2018;49(6):26-33.

13. Dehghannyieri N, Salehi T, Asadinoghabi AA. Assessing the quality of work life, productivity of nurses and their relationship. Iranian Journal of Nursing Research. 2008;3(9):27-37. [Persian]

14. Saber S, Borhani F, Navidian A, Ramezani T, Rezvani Amin M, Kianain T. The relationship between productivity and quality of working life in nurses of Kerman University of Sciences Hospitals in 2012. Bioethics Journal. 2012;3(9):143-66.

15. Salam Zadeh Y, Mansoori H, Farid D. Study of the relation between quality of work life and productivity of human resources in health care institutes-a case study among nurses in Shahid Sadughi Hospital in Yazd. Nursing And Midwifery Journal. 2008;6(2):60-70.

16. Razak NA, Ma'amor H, Hassan N. Measuring reliability and validity instruments of work environment towards quality work life. Procedia Economics and Finance. 2016;37:520-8.

17. Torre M, Popper MS, Bergesio A. Burnout prevalence in intensive care nurses in Argentina. Enfermería Intensiva (English ed.). 2019;30(3):108-15. 
18. Loft MI, Jensen CS. What makes experienced nurses stay in their position? A qualitative interview study. J Nurs Manag. 2020;28(6):1305-16.

19. Zajc JC, Kohont A. Impacts of work intensity on employees' quality of work, life and health. Teorija in Praksa. 2017;54(2):209-23.

20. Nasirizade M, Amouzeshi Z, Unesi Z, Vagharseyyedin SA, Biabani F, Bahrami M. The Relationship Between Quality of Work Life and Organizational Effectiveness Among Hospital Nurses. Modern Care Journal. 2017 31;14(1). [Persian]

21. Phan GT, Vo TQ. A literature review on quality of working life: A case of healthcare workers. J Appl Pharmac Sci. 2016;6(7):193-200.

22. Sansoni JE, Grootemaat PE, Seraji HR, Blanchard MB, Snoek M. Targeting integrated care to those most likely to need frequent health care: a review of social and clinical risk factors. Australia. 2015.

23. Kelbiso L, Belay A, Woldie M. Determinants of quality of work life among nurses working in Hawassa town public health facilities, South Ethiopia: a cross-sectional study. Nursing Research and Practice. 2017;2017.

24. Bakhshi E, Kalantari R. Investigation of quality of work life and its relationship with job performance in health care workers. Journal of Occupational Hygiene Engineering. 2017;3(4):31-7. [Persian]

25. Mohammadi M, Mozaffari N, Dadkhah B, Etebari Asl F, Etebari Asl Z. Study of work-related quality of life of nurses in Ardabil Province Hospitals. J Health Care. 2017;19(3):108-6. [Persian].

26. Attridge C, Callahan M. Nurses' perspectives of quality work environments. Canad J Nurs Administ. 1990;3(3):18-24.

27. Hood JN, Smith HL. Quality of work life in home care. The contribution of leaders' personal concern for staff. J Nur Administr. 1994;24(1):40-7.

28. Brooks BA, Anderson MA. Defining quality of nursing work life. Nursing Economics. 2005;23(6):319-26.

29. Dehghan Nayeri N, Salehi T, Ali Asadi Noghabi A. Quality of work life and productivity among Iranian nurses. Contemporary nurse. 2011;39(1):106-18.

30. Gu J, Sood N, Dunn A, Romley J. Productivity growth of skilled nursing facilities in the treatment of post-acute-care-intensive conditions. PloS one. 2019;14(4):e0215876.

31. Doostmohammadi H, Mirzaee A, Safavi M. The study of the relationship between job stress and productivity among nurses in selected hospitals of Islamic Azad University. Medical Science Journal of Islamic Azad Univesity-Tehran Medical Branch. 2018;28(4):325-32. [Persian]

32. Carvalho DP, Rocha LP, Tomaschewski-Barlem JG, Barlem EL, Cecagno D, Dalmolin GD. Productivity versus workloads in the nursing working environment. Revista da Escola de Enfermagem da USP. 2018;51.

33. Farsi Z, Habibi H, Lashkari MH. Relationship between productivity and burnout in nurses of military hospitals in Tehran. Journal of Archives in Military Medicine. 2014;2(1). [Persian]

34. Oki K. The history of a mother factory. Annals Busin Administ Sci. 2016;15(1):29-48.

35. Suleiman K, Hijazi Z, Al Kalaldeh M, Sharour LA. Quality of nursing work life and related factors among emergency nurses in Jordan. J Occup Health. 2019;61(5):398-406.

36. Zareei E, Rajaei R. The Relationship between Quality of Work Life and Job Desirability in Hospital Staff: A Case Study. Health Quarterly Journal. 2015;2(3):25-31. [Persian]

37. Walton RE. Quality of working life: what is it. Sloan management review. 1973;15(1):11-21.

38. Goldsby E, Goldsby M, Neck CB, Neck CP. Under pressure: Time management, selfleadership, and the nurse manager. Adminis Sci. 2020;10(3):38.

39. Okazaki E, Nishi D, Susukida R, Inoue A, Shimazu A, Tsutsumi A. Association between working hours, work engagement, and work productivity in employees: A cross-sectional study of the Japanese Study of Health, Occupation, and Psychosocial Factors Relates Equity. $J$ Occup Health. 2019;61(2):182-8.

40. Caruso CC. Negative impacts of shiftwork and long work hours. Rehabilitation Nursing. 2014;39(1):16-25. 
41. Prasetya TA, Mukhadiroh L, Farapti, Chesoh S, Lim A. Factors Contributing to Nurse Productivity in Public Hospitals in Surabaya, Indonesia. Hospital Topics. 2020;98(4):145-54.

42. Najafi F, Kermansaravi F, Gangoozehi E. The relationship between general health and quality of work life of nurses working in Zahedan teaching hospitals. Iranian Journal of Rehabilitation Research in Nursing. 2018;4(2):53-9. [Persian]

43. Habibzadeh H, Khalkhali HR, Mohamadpor Y. The relationship between nurses' quality of work life and their clinical competency. Journal of Urmia Nursing \& Midwifery Faculty. 2012;10(3):332-9. [Persian]

44. Almalki MJ, FitzGerald G, Clark M. Quality of work life among primary health care nurses in the Jazan region, Saudi Arabia: a cross-sectional study. Human resources for health. 2012;10(1):1-3.

45. Azarrang SH, Yaghmaei F, Shiri M. Correlation dimensions of quality of work life of nurses and demographic characteristics. Iranian Journal Of Nursing Research. 2013;7(27):18-24. [Persian]

46. Fernandes RB, Martins BS, Caixeta RP, Antonialli LM. Quality of Work Life: an evaluation of Walton model with analysis of structural equations. Espacios. 2017;38(03). 